In cooperation with the Colorado Water Conservation Board and Colorado River Water Conservation District

\title{
Hydraulic, Geomorphic, and Trout Habitat Characteristics of the Lake Fork of the Gunnison River in Hinsdale County, Lake City, Colorado, Water Years 2010-2011
}

Scientific Investigations Report 2015-5043 


\section{Hydraulic, Geomorphic, and Trout Habitat Characteristics of the Lake Fork of the Gunnison River in Hinsdale County, Lake City, Colorado, Water Years 2010-2011}

By Cory A. Williams, Rodney J. Richards, and Keelin R. Schaffrath

In cooperation with the Colorado Water Conservation Board and

Colorado River Water Conservation District

Scientific Investigations Report 2015-5043 


\title{
U.S. Department of the Interior SALLY JEWELL, Secretary
}

\section{U.S. Geological Survey \\ Suzette M. Kimball, Acting Director}

\author{
U.S. Geological Survey, Reston, Virginia: 2015
}

For more information on the USGS - the Federal source for science about the Earth, its natural and living resources, natural hazards, and the environment—visit http://www.usgs.gov or call 1-888-ASK-USGS.

For an overview of USGS information products, including maps, imagery, and publications, visit http://www.usgs.gov/pubprod/.

Any use of trade, firm, or product names is for descriptive purposes only and does not imply endorsement by the U.S. Government.

Although this information product, for the most part, is in the public domain, it also may contain copyrighted materials as noted in the text. Permission to reproduce copyrighted items must be secured from the copyright owner.

Suggested citation:

Williams, C.A., Richards, R.J., and Schaffrath, K.R., 2015, Hydraulic, geomorphic, and trout habitat conditions of the Lake Fork of the Gunnison River in Hinsdale County, Lake City, Colorado, Water Years 2010-2011: U.S. Geological Survey Scientific Investigations Report 2015-5043, 28 p., http://dx.doi.org/10.3133/sir20155043.

ISSN 2328-0328 (online) 


\section{Contents}

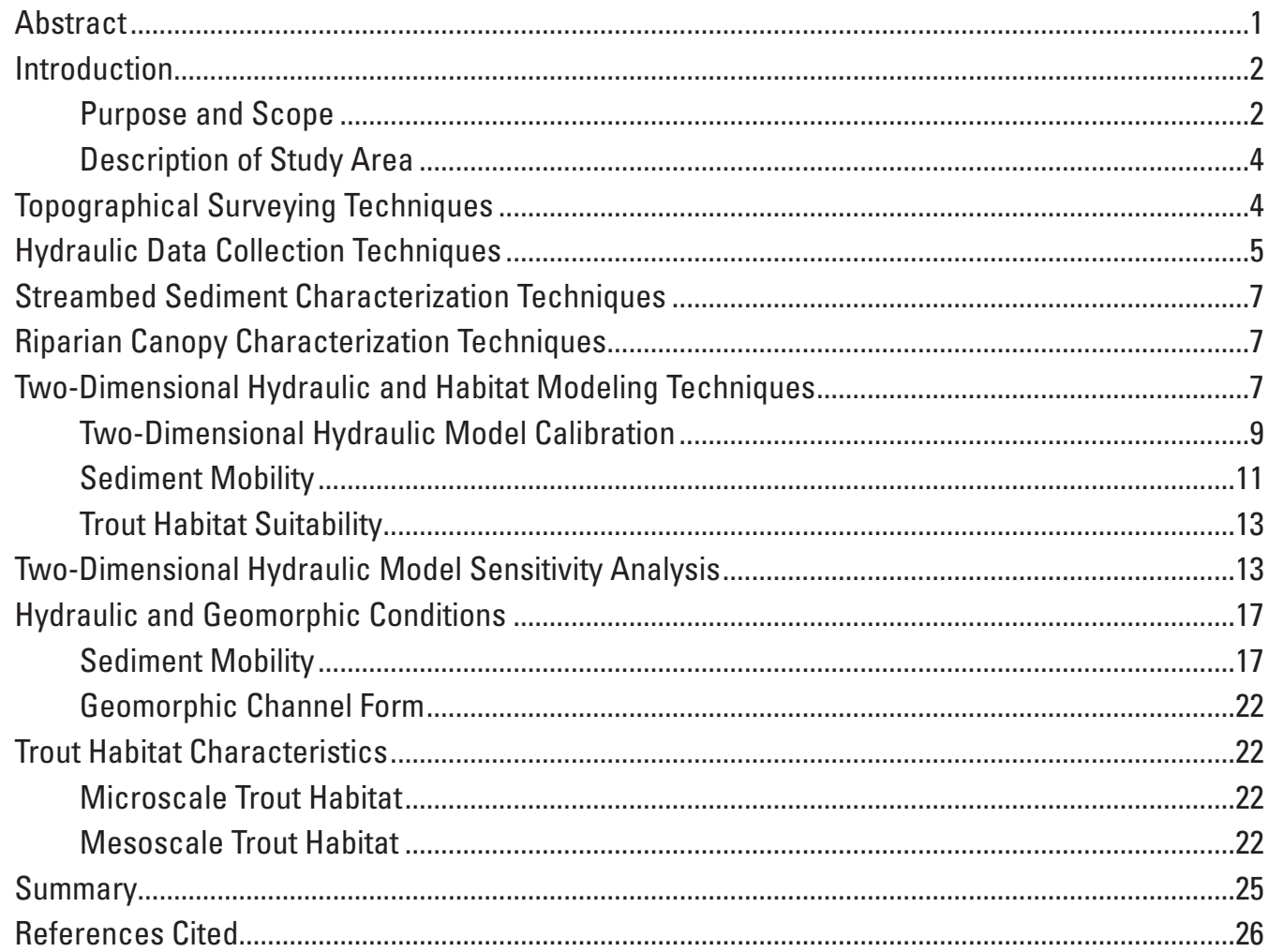

\section{Figures}

1. Map of study area for the Lake Fork of the Gunnison River at Lake City, Colorado ..........3

2. Hydrograph showing daily statistics for the Lake Fork of the Gunnison River at U.S. Geological Survey streamflow-gaging station 09124500, water years 1938 through 2010

3. Map of study reach with pressure transducers, grain-size sample locations, and cross-section locations for the Lake Fork of the Gunnison River at Lake City, Colorado.

4. Riparian canopy density assessment locations in the Lake Fork of the Gunnison River near Lake City, Colorado, August 2011 ...............................................................

5. Map of Multidimensional Surface Water Modeling System grids of the upper and lower reaches

6. Graph showing water-surface elevations for the best-fit flow simulations for $A, 150$ cubic feet per second; $B, 260$ cubic feet per second; and $C, 1,600$ cubic feet per second streamflows

7. Habitat suitability curves for the three life stages of brown trout and cutthroat trout

8. Flow frequency curve for the Lake Fork of the Gunnison River at Lake City, Colorado 
9. Sediment-size characteristics of the five sampling sites.

10. Shear stress and water-surface elevation plots at $A$, cross-section 2;

$B$, cross-section 3 ; and $C$, cross-section 4

11. Shear stress and water-surface elevation plots at $A$, cross-section 5 ;

$B$, cross-section $6 ; C$, cross-section 7 ; and $D$, cross-section 8

12. Reach-scale assessment of sediment mobility in the upper reach $(A-C)$ and lower reach (D-F) of the Lake Fork of the Gunnison River at streamflows of 400; 900; and 1,800 ft $3 / \mathrm{s}$, respectively.

13 Plotting positions of two surveyed reaches of the Lake Fork of the Gunnison River near Lake City, Colorado, in comparison to thresholds for meandering and braided channel patterns.

14. Weighted-usable habitat for the adult, juvenile, and fry life stages of the cutthroat and brown trout in the study reach of the Lake Fork of the Gunnison River

\section{Tables}

1. Summary of the lateral eddy viscosity and model diagnostics for the best-fit twodimensional hydraulic and habitat model simulations.

2. Mesoscale-habitat suitability ranges of habitat type for cutthroat and brown trout .....15

3. Results from the analysis of the sensitivity of the lateral eddy viscosity parameter for three of the streamflows simulated in the multidimensional flow model for the upper and lower study reaches on the Lake Fork

4. Results from the analysis of the sensitivity of the roughness parameter $\left(Z_{0}\right)$ for three of the streamflows simulated in the two-dimensional flow model for the upper and lower study reaches on the Lake Fork

5. Sediment particle-size characteristics for the five sites sampled from August 4 to August 6, 2010, and August 18, 2011 (GS1-GS4 and GS-5, respectively) in the Lake Fork study area

6. Results from flow-frequency curves and simulation results from the multidimensional flow model showing microscale-habitat suitability total weighteduseable habitat in a typical year for cutthroat and brown trout.

7. Mesoscale-habitat characteristics for cutthroat and brown trout during typical base-flow conditions in the Lake Fork near Lake City, Colorado 


\section{Conversion Factors}

\begin{tabular}{|c|c|c|}
\hline Multiply & By & To obtain \\
\hline \multicolumn{3}{|c|}{ Length } \\
\hline millimeter $(\mathrm{mm})$ & 0.03937 & inch (in.) \\
\hline meter $(\mathrm{m})$ & 3.281 & foot $(\mathrm{ft})$ \\
\hline meter $(\mathrm{m})$ & 1.094 & yard (yd) \\
\hline kilometer (km) & 0.6214 & mile (mi) \\
\hline inch (in.) & 2.54 & centimeter $(\mathrm{cm})$ \\
\hline feet $(\mathrm{ft})$ & 0.3048 & meter $(\mathrm{m})$ \\
\hline miles (mi) & 1.609 & kilometer $(\mathrm{km})$ \\
\hline \multicolumn{3}{|c|}{ Area } \\
\hline square meter $\left(\mathrm{m}^{2}\right)$ & 0.0002471 & acre \\
\hline square meter $\left(\mathrm{m}^{2}\right)$ & 10.76 & square foot $\left(\mathrm{ft}^{2}\right)$ \\
\hline \multicolumn{3}{|c|}{ Volume } \\
\hline cubic meter $\left(\mathrm{m}^{3}\right)$ & 35.31 & cubic foot $\left(\mathrm{ft}^{3}\right)$ \\
\hline \multicolumn{3}{|c|}{ Flow rate } \\
\hline cubic meter per second $\left(\mathrm{m}^{3} / \mathrm{s}\right)$ & 70.07 & acre-foot per day (acre-ft/d) \\
\hline meter per second (m/s) & 3.281 & foot per second (ft/s) \\
\hline cubic meter per second $\left(\mathrm{m}^{3} / \mathrm{s}\right)$ & 35.31 & cubic foot per second $\left(\mathrm{ft}^{3} / \mathrm{s}\right)$ \\
\hline cubic meter per day $\left(\mathrm{m}^{3} / \mathrm{d}\right)$ & 35.31 & cubic foot per day $\left(\mathrm{ft}^{3} / \mathrm{d}\right)$ \\
\hline cubic feet per second $\left(\mathrm{ft}^{3} / \mathrm{s}\right)$ & 0.02832 & cubic meter per second $\left(\mathrm{m}^{3} / \mathrm{s}\right)$ \\
\hline \multicolumn{3}{|c|}{ Mass } \\
\hline kilogram (kg) & 2.205 & pound avoirdupois (lb) \\
\hline \multicolumn{3}{|c|}{ Pressure } \\
\hline pascal $(\mathrm{Pa})$ & 1 & Newton per square meter \\
\hline
\end{tabular}

Temperature in degrees Celsius $\left({ }^{\circ} \mathrm{C}\right)$ may be converted to degrees Fahrenheit $\left({ }^{\circ} \mathrm{F}\right)$ as ${ }^{\circ} \mathrm{F}=\left(1.8 \times{ }^{\circ} \mathrm{C}\right)+32$.

Temperature in degrees Fahrenheit $\left({ }^{\circ} \mathrm{F}\right)$ may be converted to degrees Celsius $\left({ }^{\circ} \mathrm{C}\right)$ as ${ }^{\circ} \mathrm{C}=\left({ }^{\circ} \mathrm{F}-32\right) / 1.8$.

Vertical coordinate information is referenced to the North American Vertical Datum of 1988 (NAVD 88) and Geoid 2003 (US Conus). Horizontal coordinate information was referenced to the North American Horizontal Datum of 1983 (NAD83).

Water Year (WY) is defined as beginning October 1 and continuing through September 30 of the following year. 


\section{Acronyms and Abbreviations}

$\begin{array}{ll}\text { CDOT } & \text { Colorado Department of Transportation } \\ \mathrm{ft}^{3} / \mathrm{s} & \text { cubic feet per second } \\ \text { RTK-GPS } & \text { Real-Time Kinematic mode Global Positioning System } \\ \text { TIN } & \text { Triangulated Irregular Network } \\ \text { USGS } & \text { U.S. Geological Survey }\end{array}$




\title{
Hydraulic, Geomorphic, and Trout Habitat Characteristics of the Lake Fork of the Gunnison River in Hinsdale County, Lake City, Colorado, Water Years 2010-2011
}

\author{
By Cory A. Williams, Rodney J. Richards, and Keelin R. Schaffrath
}

\section{Abstract}

Channel rehabilitation, or reconfiguration, to mitigate a variety of riverine problems has become a common practice in the western United States. However, additional work to monitor and assess the channel response to, and the effectiveness of, these modifications over longer periods of time (decadal or longer) is still needed. The Lake Fork of the Gunnison River has been an area of active channel modification to accommodate the needs of the Lake City community since the 1950s. The Lake Fork Valley Conservancy District began a planning process to assess restoration options for a reach of the Lake Fork in Lake City to enhance hydraulic and ecologic characteristics of the reach. Geomorphic channel form is affected by landuse changes within the basin and geologic controls within the reach. The historic channel was defined as a dynamic, braided channel with an active flood plain. This can result in a natural tendency for the channel to braid. A braided channel can affect channel stability of reconfigured reaches when a single-thread meandering channel is imposed on the stream. The U.S. Geological Survey, in cooperation with the Colorado Water Conservation Board and Colorado River Water Conservation District, began a study in 2010 to quantify existing hydraulic and habitat conditions for a reach of the Lake Fork of the Gunnison River in Lake City, Colorado. The purpose of this report is to quantify existing Lake Fork hydraulic and habitat conditions and establish a baseline against which post-reconfiguration conditions can be compared. This report (1) quantifies the existing hydraulic and geomorphic conditions in a 1.1-kilometer section of the Lake Fork at Lake City that has been proposed as a location for future channel-rehabilitation efforts, (2) characterizes the habitat suitability of the reach for two trout species based on physical conditions within the stream, and (3) characterizes the current riparian canopy density.

The FaSTMECH computational flow-model within MD_SWMS was selected to characterize the effects of streamflow on hydraulic and habitat-suitability conditions for a study reach of the Lake Fork. Habitat suitability was evaluated for cutthroat (Oncorhynchus clarkii) and brown trout (Salmo trutta morpha fario) fry, juveniles, and adults. Microscale (point locations) and mesoscale (reach features) habitats were assessed using the combination of field observations, measurements, and hydraulic simulations within the study reach of the Lake Fork. Microscale trout habitat, presented as weighted usable area, generally increased as streamflow increased for both trout species and all life stages. Areas of suitable microscale habitat occur along the banks for flows of 900 cubic feet per second $\left(\mathrm{ft}^{3} / \mathrm{s}\right)$ and less. Out-of-bank areas became more substantial contributors to overall habitat availability for flows of $1,300 \mathrm{ft}^{3} / \mathrm{s}$ or more when compared to other features. Adult habitat, for both trout species, was the most abundant habitat type for nearly all streamflows. In general, the upper reach provided 2-3 times more available habitat than the lower reach for both trout species.

Mesoscale trout habitat of the Lake Fork was assessed based on the conditions present in the $150 \mathrm{ft}^{3} / \mathrm{s}$ flow simulation as well as field observation. Both the upper and lower reach is primarily characterized as riffle/run habitat. The presence of pool habitat was limited throughout both reaches and occurred along the channel margins. For both reaches, the pool habitat was less than 5 percent of the total wetted area, a percentage that is substantially lower than the recommendations for sustainable populations of 40-70 percent. Areas of cover were adjacent to potential drift feeding areas in the lower reach, and often occurred within the same pool habitat. This may favor energy expenditure ratios of both fish species, wherein little energy is needed to acquire adequate food sources.

Sediment mobility is an important process for flushing fine sediments from within the gravel frameworks. Evaluations of channel and flow characteristics at cross-section locations 2-8 show a range of streambed mobility. In general, boundary shear stress and streambed mobility increase with increases in streamflow. Within the cross sections, the greatest boundary shear stress occurs towards the center of the channel. Reachscale assessment of sediment mobility in the lower reach shows increased streambed mobility. This is due in part to smaller grain sizes in the lower reach, but may also reflect the greater extent of channel alterations, specifically the temporary berms constructed by CDOT in the late 1980s and 1990s, present in this reach. 


\section{Introduction}

The Lake Fork of the Gunnison River (hereafter, Lake Fork) has been an area of active channel modification since the 1950s to accommodate the needs of the Lake City community (Lake Fork Valley Conservancy, 2010). Historically, the Lake Fork was characterized by its braided channel which frequently overtopped its banks and created an active and dynamic flood plain (Lake Fork Valley Conservancy, 2010). However, beginning in the 1950s, increased rates of land-use change within Lake City resulted in the straightening and channelization of the Lake Fork to promote channel stability and development of riverfront properties (Lake Fork Valley Conservancy, 2010).

Reduced channel width, sinuosity, and riparian habitat have been noted in the Lake Fork as well as Henson Creek, a smaller tributary located upstream from Lake City (Lake Fork Valley Conservancy, 2010) (fig. 1). Failures of sediment-retention structures (cribbing piles) on Henson Creek in the 1960s and 1970s have contributed large volumes of sediment into the fluvial system. In the late 1980s and early 1990s, the Colorado Department of Transportation (CDOT) constructed temporary berm structures along the river on the north side of town to protect the highway from channel migration until permanent structures could be completed (Lake Fork Valley Conservancy, 2010). The constructed berms may be a potential source of channel instability and sediment inputs, because they were not designed to withstand high-flow conditions. Additional areas along the north side of town were also straightened by CDOT and U.S. Army Corps of Engineers in the 1980s (Lake Fork Valley Conservancy, 2010).

The Lake Fork Valley Conservancy District began a planning process to assess restoration options for a reach of the Lake Fork in Lake City to enhance hydraulic and ecologic characteristics of the reach (Lake Fork Valley Conservancy, 2010). In part, candidacy for the proposed channel-restoration efforts is based on the effects of similar efforts in other areas of the Lake Fork. Beginning in the last few decades, several groups have completed channel reconfiguration efforts downstream from the study area on the Lake Fork to improve aquatic habitat and channel stability. In 1997, 35 kilometers $(\mathrm{km})$ downstream from Lake City, a 3-km reach of the Lake Fork was reconfigured. The objectives of these earlier efforts were to improve habitat for brown and rainbow trout (Lake Fork Valley Conservancy, 2010).

Reshaping the downstream channel banks and river pools during this earlier effort was done to improve riparian habitat, vegetation, and streambank stability and to reduce sediment sources that were believed to be impairing the fisheries (Lake Fork Valley Conservancy, 2010). Reconfigured channel efforts carried out by the Colorado Division of Wildlife and the Bureau of Land Management included reshaping of the channel and placing large boulders to improve fish habitat and increasing channel stability (Lake Fork Valley Conservancy, 2010). Additional planting of riparian vegetation was expanded in areas where the channel widths were decreased
Figure 1. Map of study area for the Lake Fork of the Gunnison River at Lake City, Colorado._-Following page

during channel reshaping. Following reconfigured channel efforts, the total fish biomass (weight of fish across all age classes per acre of stream, in pounds per acre [lbs/acre]) increased from approximately 40 to $100 \mathrm{lbs} / \mathrm{acre}$, an indication that the reconfiguration efforts improved fish habitat (Lake Fork Valley Conservancy, 2010).

Channel rehabilitation, or reconfiguration, to mitigate a variety of riverine problems has become a common practice in the western United States. Reasons for channel rehabilitation include restoration to more natural or historical conditions, improved water conveyance in flood-prone areas, mitigation of unstable streambeds and streambanks, increased sediment transport, enhancement of aquatic and riparian habitat, improved water quality, and recreation. Numerous private entities and resource-management agencies have attempted to modify stream channels by using designs based on different geomorphic philosophies and classification schemes. However, additional work to monitor and assess the channel response to, and the effectiveness of, these modifications over longer periods of time (decadal or longer) is still needed. To address this need, the U.S. Geological Survey (USGS) is engaged in a program designed to monitor and assess selected river reaches that have undergone reconfiguration (Elliott and Parker, 1999).

The basis for determining the "success" of a channelreconfiguration project is often not made through analysis of quantifiable metrics, leaving little information for resource managers, planners, and designers to use to determine the effectiveness and durability of channel restoration techniques used for stream rehabilitation (including biological response) and channel stability. The U.S. Geological Survey, in cooperation with the Colorado Water Conservation Board and Colorado River Water Conservation District, began a study in 2010 to quantify existing hydraulic and habitat conditions for a reach of the Lake Fork in Lake City, Colorado (Colo.).

\section{Purpose and Scope}

The purpose of this report is to quantify existing Lake Fork hydraulic and habitat conditions and establish a baseline against which post-reconfiguration conditions can be compared. This report (1) quantifies the existing hydraulic and geomorphic conditions in a 1.1-kilometer $(\mathrm{km})$ section of the Lake Fork at Lake City that has been proposed as a location for future channel-rehabilitation efforts, (2) characterizes the habitat suitability of the reach for two trout species based on physical conditions within the stream, and (3) characterizes the current riparian canopy density. This characterization describes existing channel conditions and establishes a baseline for post-reconfiguration comparisons for resource managers to evaluate restoration project success. 


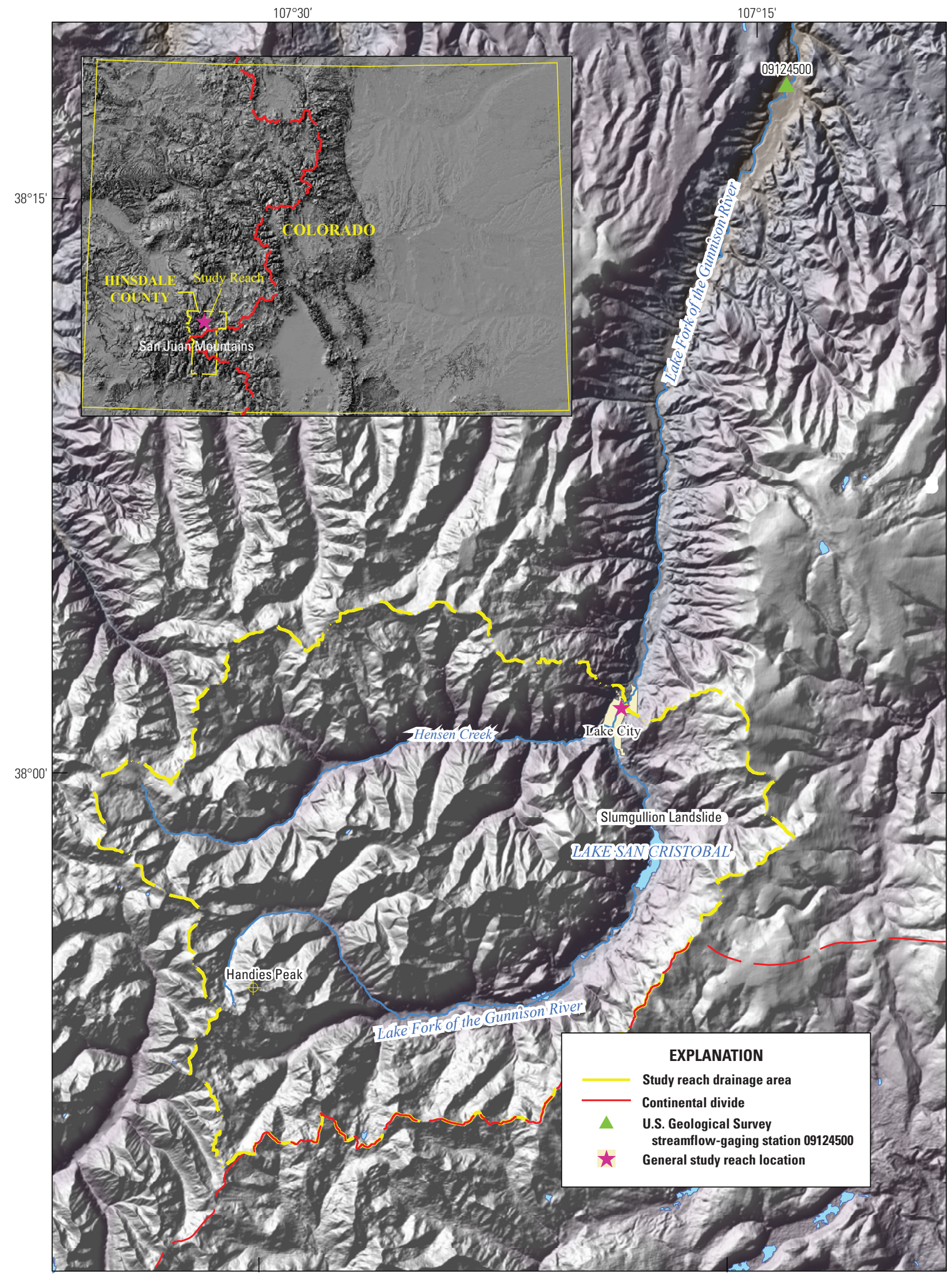

Base from U.S. Geological Survey National Elevation Dataset 30 meter elevation model showing land surface elevations shaded at 2-meter intervals scale 1:265,000

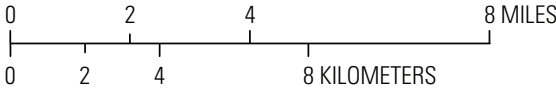


This report does not aim to determine limiting conditions for these species. Instead, this report quantifies the availability of trout habitat characteristics based on physical conditions within the stream. No considerations were made related to inter-species interactions.

\section{Description of Study Area}

The study reach is located in the town of Lake City, Colo., along the Lake Fork. Lake City is a small mountain town with a population of 375 year-round residents (U.S. Census Bureau, 2011). The Lake Fork originates in the northern portion of the San Juan Mountain Range and flows in a northern direction (fig. 1). The study reach is located at an elevation of 2,643 meters ( $\mathrm{m}$ ) and the drainage area upstream from the study reach encompasses 544 square kilometers $\left(\mathrm{km}^{2}\right)$ of the 1,144-km² Lake Fork Basin (U.S. Geological Survey, 2010b). Most of the land in the Lake Fork Basin is federally owned and managed by the Bureau of Land Management and U.S. Department of Agriculture Forest Service. The remainder of land is privately owned except for Lake San Cristobal, which is owned and managed by the local government.

Land cover in the basin varies with elevation (Homer and others, 2004) and the highest elevations include barren and grassland classifications. Tree line in Colorado occurs at an elevation of approximately 3,500 m (Pielke and others, 2003). Both deciduous and coniferous forests are found throughout the basin and along stream margins (Homer and others, 2004).

Local climate is typical of other mountainous areas of western Colorado. Precipitation tends to increase with elevation while temperatures decrease with elevation (Pielke and others, 2003). The majority of precipitation falls as snow and is stored as snowpack through the winter months. The average annual precipitation in Lake City is 14.1 inches (in.) of water, and the average annual snowfall accumulation is 82.8 in. (based on data from August 1, 1948 through December 21, 2008 from the Western Regional Climate Center, 2011). Average annual maximum temperature in Lake City is $55.7^{\circ} \mathrm{F}$, and the average annual minimum is $22.4^{\circ} \mathrm{F}$ (Western Regional Climate Center, 2011).

The hydrology of the Lake Fork is governed by snowpack accumulations and spring temperatures which drive snowmelt-runoff. The annual streamflow pattern is characterized by streamflow increases that begin in April, peak in May and June, and finally decrease in July and August (U.S. Geological Survey, 2010a). The Lake Fork of the Gunnison River is monitored at USGS streamflow-gaging station 09124500, Lake Fork at Gateview, Colo. (hereafter, Gateview). The drainage area of Gateview is $964 \mathrm{~km}^{2}$, and it is located approximately 35 river $\mathrm{km}$ downstream from the study reach. No major tributaries or diversions occur in the Lake Fork between the study reach and the streamflowgaging station. A summary of daily streamflow conditions is shown in figure 2 including: maximum, 75 th percentile, mean, 25 th percentile, and minimum. The highest recorded streamflow was 2,720 cubic feet per second $\left(\mathrm{ft}^{3} / \mathrm{s}\right)$, July 10,1983 , with the lowest daily mean streamflow of $21 \mathrm{ft}^{3} / \mathrm{s}$, recorded January 3, 2002 (U.S. Geological Survey, 2010a). Additional water-quality and streamflow data are available from the USGS National Water Information System (NWIS) website at http://waterdata.usgs. gov/co/nwis.

The dominating geology in and around Lake City is Tertiary volcanic deposits (Tweto, 1979). The extensive volcanic activity, along with intrusions and mineralization, created widespread distributions of ore bodies in the San Juan Mountains that were deposited during the late-Tertiary period (Tweto and Sims, 1963; Burbank and others, 1947). Historical mining activities in the region were driven by the discovery of gold and silver deposits near Lake City. Relic mining cribbing piles have introduced sediment into Henson Creek, which transported it into the study reach (Lake Fork Valley Conservancy, 2010). This sediment may affect channel form, habitat, and toxicity.

Instabilities associated with geologic formation sequences have resulted in the unique history of the Lake Fork Valley and a history of large landslides (Tweto, 1979). Most notably, the Slumgullion landslide which occurred roughly 700 years (yr) ago was large enough to dam the Lake Fork. This landslide deposit resulted in the creation and persistence of Lake San Cristobal, the second largest natural lake in Colorado (Guzzi and Parise, 1992).

\section{Topographical Surveying Techniques}

Topographical surveying was used to map water-surface and stream channel elevations for a $1.1-\mathrm{km}$ reach at Lake Fork at Lake City (figs. 1 and 3). The majority of the surveying occurred August 2-6, 2010, with additional flood-plain surveying on May 24, 2011. Topographical surveying of water-surface elevations includes conditions present during each day of surveying as well as preserved high-flow conditions (high-water marks) from spring 2010 and 2011 identified through interpretation of sediment deposits and debris lines. Eight monumented cross sections were established in the study reach for long-term channel monitoring (fig. 3).

Surveying was completed using survey-grade Global Positioning System (GPS) equipment, operated in Real-Time Kinematic mode (RTK-GPS) to determine the elevation and coordinate locations of each surveyed point (Trimble Navigation Limited, 2009). The RTK-GPS used a stationary GPS receiver (base station) positioned over a reference benchmark and roving GPS receivers (rovers) operated by separate hand-held computers (data collectors). The RTK-GPS system calculates the locations of the rovers in real time, using the positions of orbiting NAVigation Signal Timing And Ranging (NAVSTAR) GPS satellites and a known base-station location.

All surveyed elevations (RTK-GPS) were output to a spreadsheet program in metric Northing, Easting, and Elevation format using a Universal Transverse Mercator coordinate system (UTM, Zone 12 North). Horizontal coordinate information was referenced to the North American Horizontal Datum of 


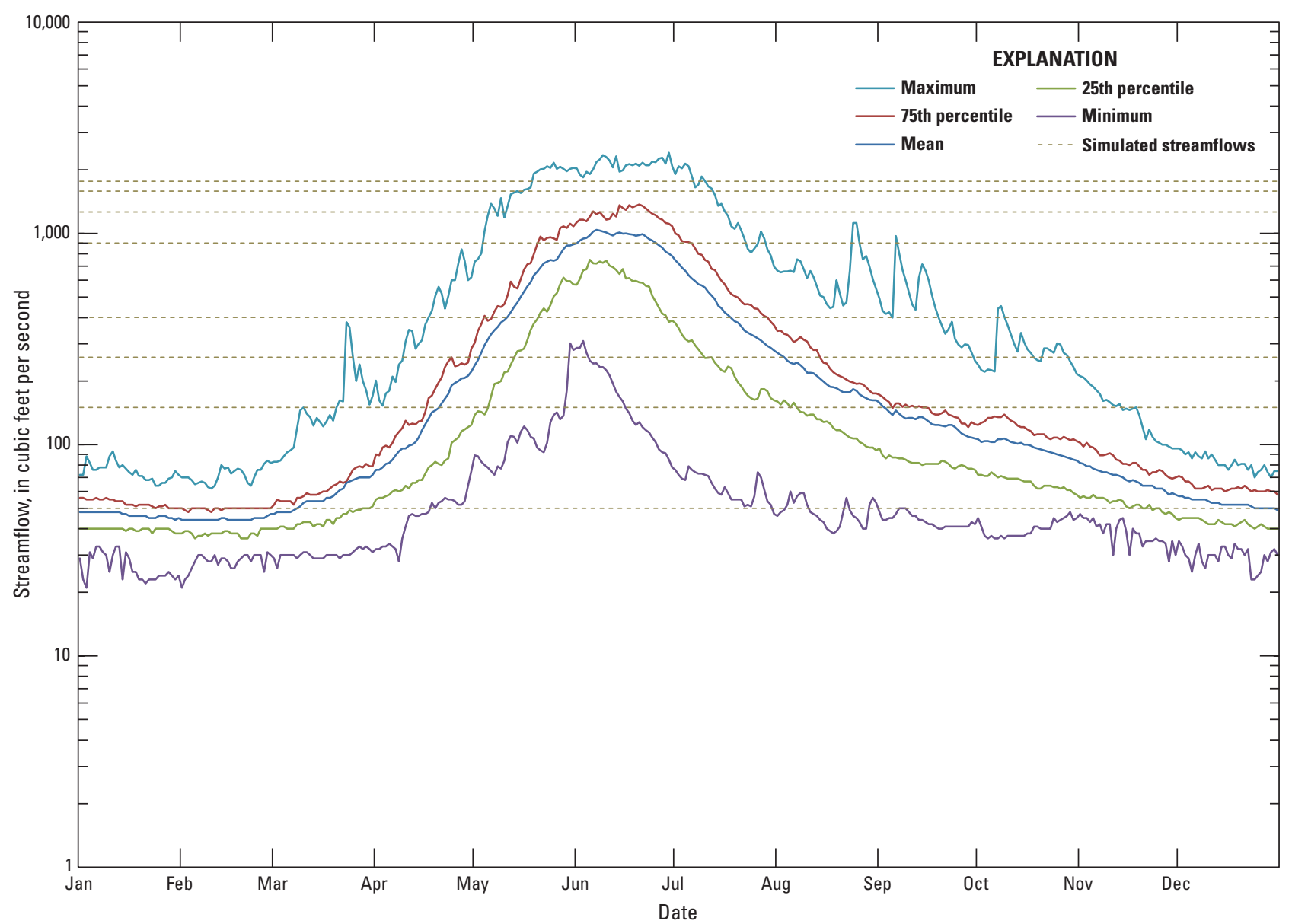

Figure 2. Hydrograph showing daily statistics for the Lake Fork of the Gunnison River at U.S. Geological Survey streamflow-gaging station 09124500, water years 1938 through 2010.

1983 (NAD83). Vertical coordinate information was referenced to the North American Vertical Datum of 1988 (NAVD 88) and Geoid 2003 (US Conus). Elevation values were visually examined for relative accuracy graphically and through inspection of GPS positional precision and diagnostic parameters.

\section{Hydraulic Data Collection Techniques}

Streamflow was measured using a FlowTracker ${ }^{\circledR}$ Handheld Acoustic Doppler Velocimeter (ADV) for wadable stream conditions and followed standard techniques outlined in Turnipseed and Sauer (2010). For unwadable flows, an Acoustic Doppler Current Profiler (ADCP) was used to measure streamflow from the 5th Street pedestrian bridge (near GS1, fig. 3) using a tethered boat, following standard techniques outlined in Mueller and Wagner (2009). Streamflow measurements were made at $40 ; 150 ; 270 ; 760$; and $1,400 \mathrm{ft}^{3} / \mathrm{s}$ between August 5, 2010 and August 1, 2011.

Onset Hobo water level loggers (model U20-001-01, unvented, pressure transducer) were used in conjunction with local vertical elevation reference markers (staff-plates) to monitor water-surface elevation at selected locations within the study reach. Pressure transducers were deployed at the upstream study-reach boundary, at approximately halfway through the study reach, and at the downstream study-reach boundary (fig. 3). Pressure transducers were placed in protective polyvinyl chloride (PVC) casings and attached to T-posts which were secured to the river bed. A fourth pressure transducer was located outside the stream at cross-section 8 (fig. 3) to record barometric-pressures changes for postprocessing corrections of the unvented, pressure-transducer readings (Freeman and others, 2004). This process resulted in a continuous record (30-minute intervals) of water-surface elevations at these three locations from August 2 to October 28, 2010; and from March 24 to August 1, 2011.

A stage-discharge rating curve based on the relation between the measured streamflow and water-surface elevation pairs was determined for the upstream study-reach boundary at cross-section 1 through least-squares regression techniques, as described by Rantz and others (1982) (fig. 3). At the remaining pressure-transducer locations, water-surface elevations corresponding to $50 ; 150 ; 260 ; 400 ; 900 ; 1,300 ; 1,600$; and 


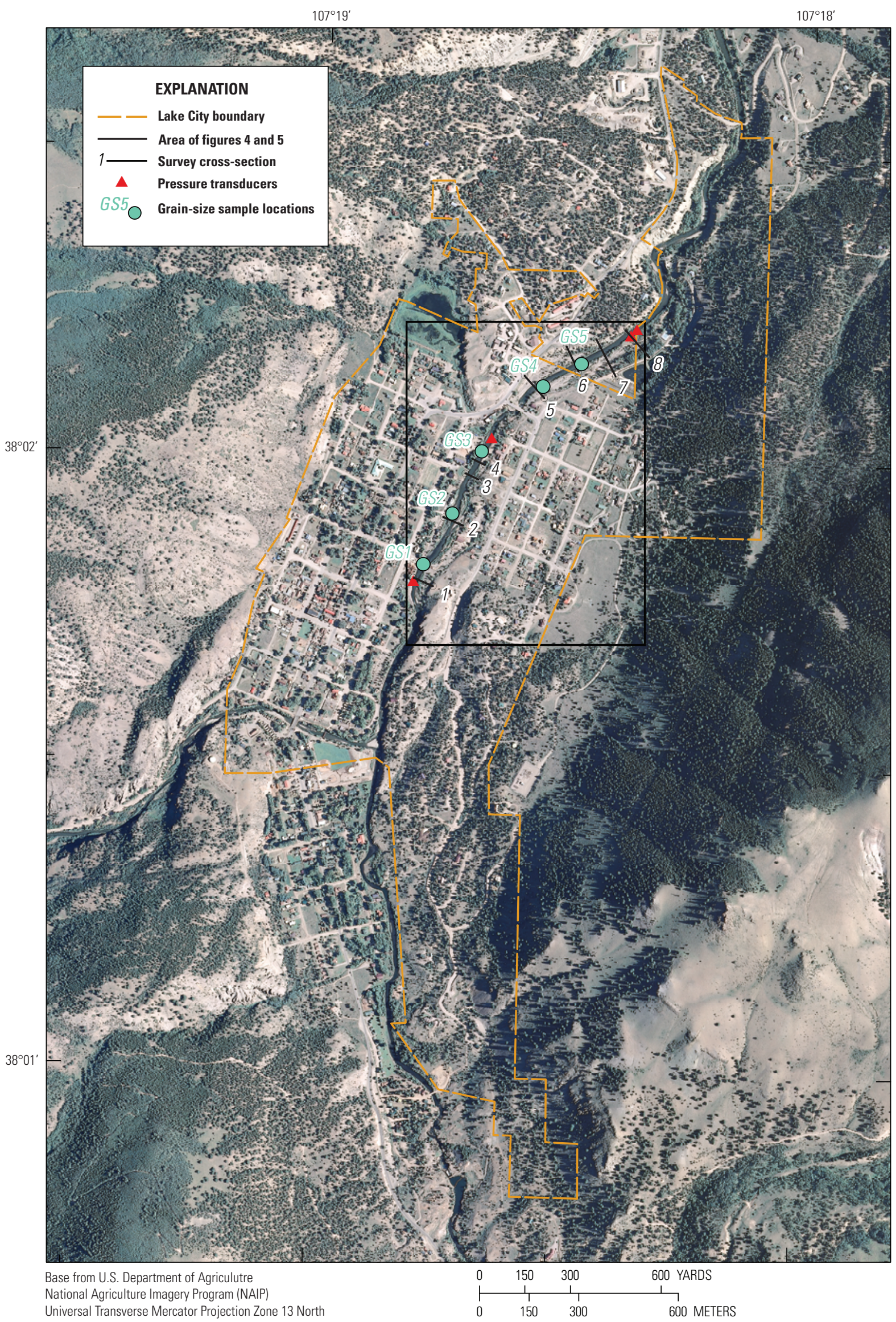


Figure 3. Map of study reach with pressure transducers, grainsize sample locations, and cross-section locations for the Lake Fork of the Gunnison River at Lake City, Colorado._Previous page

$1,800 \mathrm{ft}^{3} / \mathrm{s}$ were determined based upon the date and time of the estimated streamflow at the upstream boundary. Based on field observations, it was assumed that the streamflow at the downstream boundary was equal to the streamflow at the upstream boundary, because there were no large inflows or diversions within the reach.

High-water marks from the water year 2010 (October 1, 2009, through September 30, 2010) peak flow were identified and surveyed within the study reach; however, streamflow data were unavailable within the study reach to relate these water-surface elevations to discharge. The Gateview dataset was used to estimate the corresponding streamflow through a Maintenance of Variance 1 (hereafter, MOVE.1) equation analysis (Hirsch, 1982). The MOVE.1 equation uses data from an adjacent site (downstream in this instance) to predict streamflow for the site of interest. This methodology uses an algorithm to relate the streamflow values between sites while maintaining the natural variations in each dataset.

To determine how often a specific flow occurs each year, flow-duration curves were used to determine flow frequencies as percent of year. The flow frequency for cross-section 1 was calculated using 30 arithmetic bins following the regionalized-duration curve method for estimating flow-durations for ungaged sites (U.S. Department of Agriculture, 2009). The regionalized flow-duration curve method relates flow between two sites (a gaged site and an ungaged site of interest) by transferring a nondimensional flow-duration curve. This technique preserves the shape of the flow-duration curve and allows the magnitude of the streamflows to be scaled appropriately between sites based on standardized peak-flow values between sites. Peak-flow magnitudes (2-, 5-, 10-yr floods) were estimated based on regional regression analysis (Capesius and Stephens, 2009; U.S. Geological Survey, 2010b). The 2-yr recurrence interval peak streamflow was selected for use in this technique for consistency in methodology between the two sites (Capesius and Stephens, 2009; U.S. Geological Survey, 2010b).

\section{Streambed Sediment Characterization Techniques}

Sediment particles were measured from August 4 to August 6, 2010, and August 18, 2011 (GS1-GS4 and GS-5, respectively) at five locations in the study reach (fig. 3) to characterize the grain size of different geomorphic surfaces and to estimate channel roughness. Bars and channel margins were chosen because these areas are inundated most of the year and represent the coarser material transported within the river channel. Grain size was determined in the field using areal techniques (pebble-counts) as described by Wolman (1954). A minimum of 100 clasts were measured during each pebble count, and sampling was performed parallel to the direction of streamflow at one- or two-pace intervals along the streambed or alluvial bars. The intermediate, or "b-axis," of each sediment particle was measured to the nearest millimeter for gravel and small cobbles, and to the nearest 5 millimeters for large cobbles and small boulders. Grain-size statistics $\left(\mathrm{d}_{50}\right.$, size at the 50 th percentile, and $d_{84}$, size at the 84 th percentile; $d_{n}$ is the size at the nth percentile) were determined from the cumulativefrequency distribution function of b-axis measurements.

\section{Riparian Canopy Characterization Techniques}

Canopy density was characterized during a low-flow period (August 17-18, 2011) at multiple locations within the study area using a spherical densiometer (Model A) (Lemmon, 1956). Differences in canopy density can affect habitat cover as well as water temperatures, terrestrial insect inputs, and leafy organic inputs into the aquatic system (Lindsey and others, 1998). Four measurements were taken at each location from the center of the stream with the operator facing: upstream, downstream, towards left bank, and towards right bank (Lemmon, 1956). The percentage of the densiometer view field that was obstructed was recorded for each measurement. This provides a standardized methodology to characterize the canopy density within the stream reach. Observations are presented as rose diagrams within the study reach (fig. 4).

\section{Two-Dimensional Hydraulic and Habitat Modeling Techniques}

The Multidimensional Surface Water Modeling System (MD_SWMS) is a graphical user interface that was developed by the USGS to aid in pre- and post-processing twodimensional streamflow analysis (McDonald and others, 2001; 2005; 2006). The FaSTMECH computational flow-model within MD_SWMS was selected to characterize the effects of streamflow on hydraulic and habitat-suitability conditions for the 1.1-km study reach of the Lake Fork (Nelson and McDonald, 1997; Thompson and others, 1998; Lisle and others, 2000; Nelson and others, 2003; McDonald and others, 2005; 2006).

The FaSTMECH model uses a curvilinear orthogonal grid built upon a user-defined centerline and width that fits the path of the modeled reach. FaSTMECH is a vertically averaged two-dimensional model that simulates spatially distributed values of depth, velocity, and total bed shear stress. The resolution of the grid was defined such that there were no fewer than 10 locations along any cross-section within the wetted-channel area at the lowest simulated flow (or a spatial 


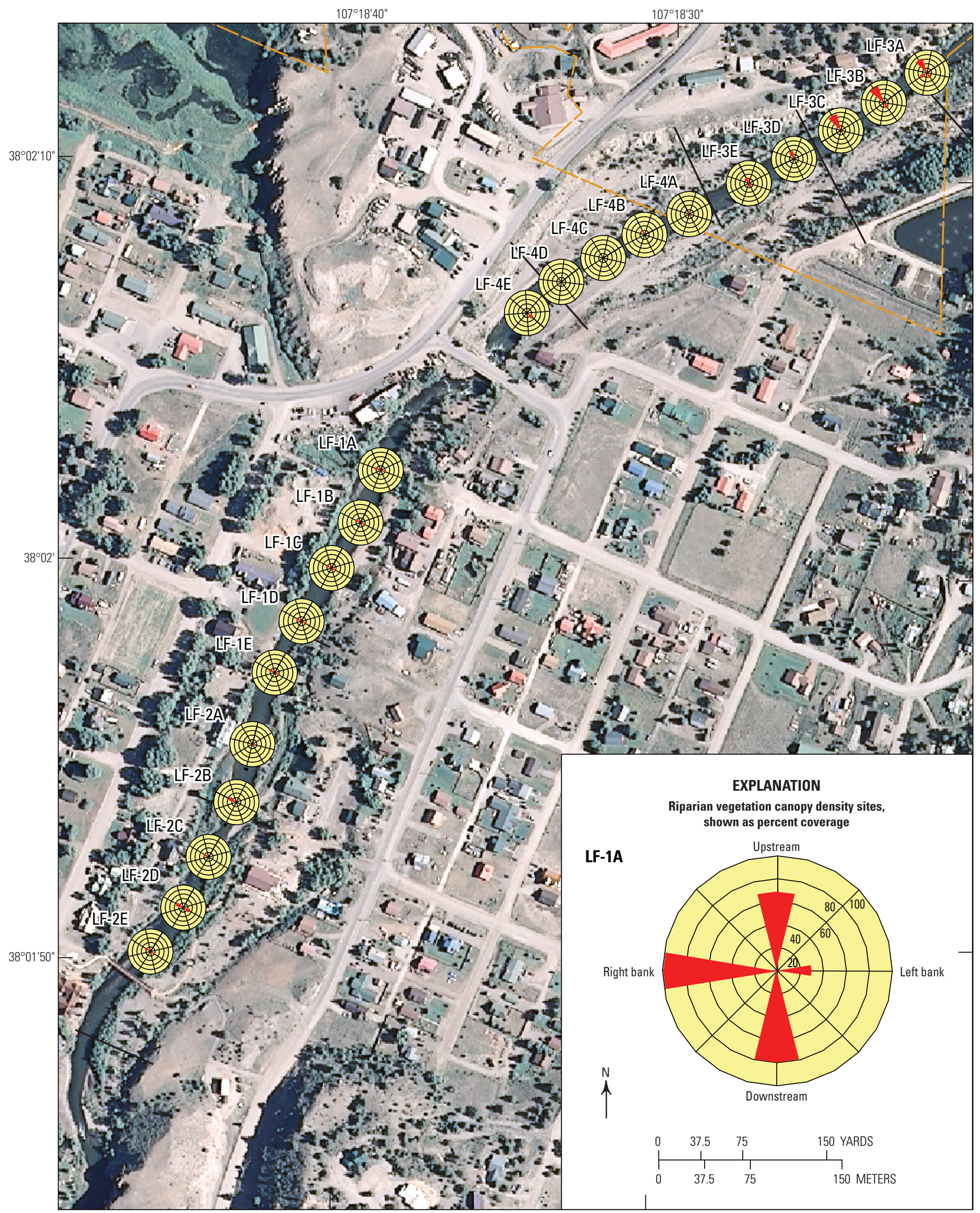

Base from U.S. Department of Agriculutre

National Agriculture Imagery Program (NAIP)

Universal Transverse Mercator Projection Zone 13 North 
Figure 4. Riparian canopy density assessment locations in the Lake Fork of the Gunnison River near Lake City, Colorado, August 2011.-Previous page

resolution of 1.0 - by $1.0-\mathrm{m}$ grid). Additional information on the interface and the model can be found in McDonald and others (2001; 2006), Nelson and McDonald (1997), and Nelson and others (2003).

Channel geometry was obtained from the topographical survey of the channel. Interpolation between measured data points was completed within the model interface elevation data to generate a suitable dataset. Aerial images were obtained from the U.S. Department of Agriculture National Agricultural Imagery Program (2011) and were used in conjunction with the survey data to best define the channel topography. Elevation data within the stream channel were interpolated in a streamwise direction between surveyed cross sections. Otherwise, interpolation of elevation data was in a cross-sectional direction. The final elevation dataset was a densely spaced set of topographic data from which a final dataset for channel geometry was created using the Triangulated Irregular Network (TIN) method (Environmental Systems Research Institute, Inc., 2010). For computational efficiency, the FastMECH model grid, derived from the final elevation dataset, was divided into upper and lower reaches (fig. 5). The grid cells in the computational grids for both reaches approximated $1.0-$ by $1.0-\mathrm{m}$. The grid in the upper reach was approximately $455 \mathrm{~m}$ long and 60 $\mathrm{m}$ wide (fig. 5). The grid in the lower reach was approximately $411 \mathrm{~m}$ long and $100 \mathrm{~m}$ wide (fig. 5).

\section{Two-Dimensional Hydraulic Model Calibration}

FaSTMECH model calibration was achieved through iterative adjustments of the roughness until the root mean squared error (RMSE) between the observed and simulated water-surface elevations was minimized. The RMSE was calculated following standard techniques (Helsel and Hirsch, 2002). Multiple techniques are available to the user for selection of the roughness parameter within the model interface. The $Z_{0}$ parameter was selected to calculate roughness, where $\mathrm{Z}_{0}$ is defined as the distance above the streambed at which the velocity is zero (Julien, 2010).

The $\mathrm{Z}_{0}$ parameter is calculated as the quotient of the grain roughness height and 30 (Julien, 2010). The grain roughness height in gravel bed rivers has been characterized as a function of grain size in a variety of ways including: $3.5 \times \mathrm{d}_{84}$ and $6.8 \times \mathrm{d}_{50}$ (Bray, 1982) and $1.25 \times \mathrm{d}_{35}$ and $3.5 \times \mathrm{d}_{90}$ (Millar and Quick, 1994). The $d_{84}$ was calculated from the five grain-size samples (three samples in the upper reach and two samples in the lower reach) which are discussed in the "Streambed Sediment Characterization Techniques" section. The average $Z_{0}$, calculated from the $d_{84}$ of the five grain-size samples, was $0.013 \mathrm{~m}$, and the same average resulted when the two reaches were considered separately.
FaSTMECH uses a constant $\mathrm{Z}_{0}$ to calculate a variable drag coefficient as a function of depth for the study reach (Rich McDonald, U.S. Geological Survey, oral commun., September 2011), where the drag coefficient is a dimensionless quantity that is used to quantify the drag or resistance of an object in a fluid. The $\mathrm{Z}_{0}$ parameter was chosen to determine channel roughness because it is based on the grain size of the streambed (a persistent condition within gravel streams for moderate time steps); $\mathrm{Z}_{0}$ is also advantageous because it is less subjective than other roughness estimates (Manning's n or Darcy-Weisbach friction factor) that are made based on visual comparisons to reference values which integrate roughness sources along the entire cross section or reach (Barnes, 1977). Another benefit to using $Z_{0}$ over other roughness estimates is that it does not change with stream depth and so requires a single characterization for the entire range of flow conditions (Julien, 2010). However, when using $\mathrm{Z}_{0}$, the characteristic roughness height for a channel is a function of scales that range from as large as the channel form to as small as the characteristic grain size of the channel, and the streambed is discretized onto a grid that may be coarser than some of the roughness scales of the channel. The model is therefore calibrated by varying the roughness height as described above.

Eight streamflow conditions were simulated: 50; 150; $260 ; 400 ; 900 ; 1,300 ; 1,600$; and $1,800 \mathrm{ft}^{3} / \mathrm{s}$. Five of the simulated streamflows had one measured water-surface elevation available located at the upstream boundary of each reach. For streamflow conditions of $150 ; 260$; and 1,600 $\mathrm{ft}^{3} / \mathrm{s}$, multiple measured water-surface elevations distributed throughout the reach allowed for more rigorous calibration of these flow simulations (fig. 6). There were 183 surveyed water-surface elevations (data points) for the $150 \mathrm{ft}^{3} / \mathrm{s}$ simulation; 110 data points for the $260 \mathrm{ft}^{3} / \mathrm{s}$ simulation; and 40 data points for the $1,600 \mathrm{ft}^{3} / \mathrm{s}$ simulation (the data points used for the $1,600 \mathrm{ft}^{3} / \mathrm{s}$ simulation were 2010 high-water marks).

For all of the flow simulations except 1,600 $\mathrm{ft}^{3} / \mathrm{s}$ (in the lower reach), the root mean squared error of the water-surface elevation was $0.09 \mathrm{~m}$ or less. The $1,600 \mathrm{ft}^{3} / \mathrm{s}$ flow simulation in the upper reach had a root mean squared error of $0.24 \mathrm{~m}$, and the predictions of water-surface elevation were consistently higher than the data points. The largest differences between the predictions and data points for this simulation occurred in the middle of the study reach (maximum was $0.58 \mathrm{~m}$ ), while the up- and downstream boundaries had smaller differences (0.11 m or less) (fig. 6C). This may indicate additional streamflow within that section of the reach that occurs outside of the simulated flow area or over estimation of channel roughness based on estimates of $Z_{0}$.

Within the hydraulic model calibration procedure, the RMSE in streamflow is used to aid in the assessment of flow simulation convergence. The RMSE in streamflow compares the observed and mean simulated streamflow for each flow condition along the computational grids. For most flow simulations, the RMSE in streamflow was less than 1.0 percent (table 1). The $50 \mathrm{ft}^{3} / \mathrm{s}$ simulation had the largest RMSE in both 


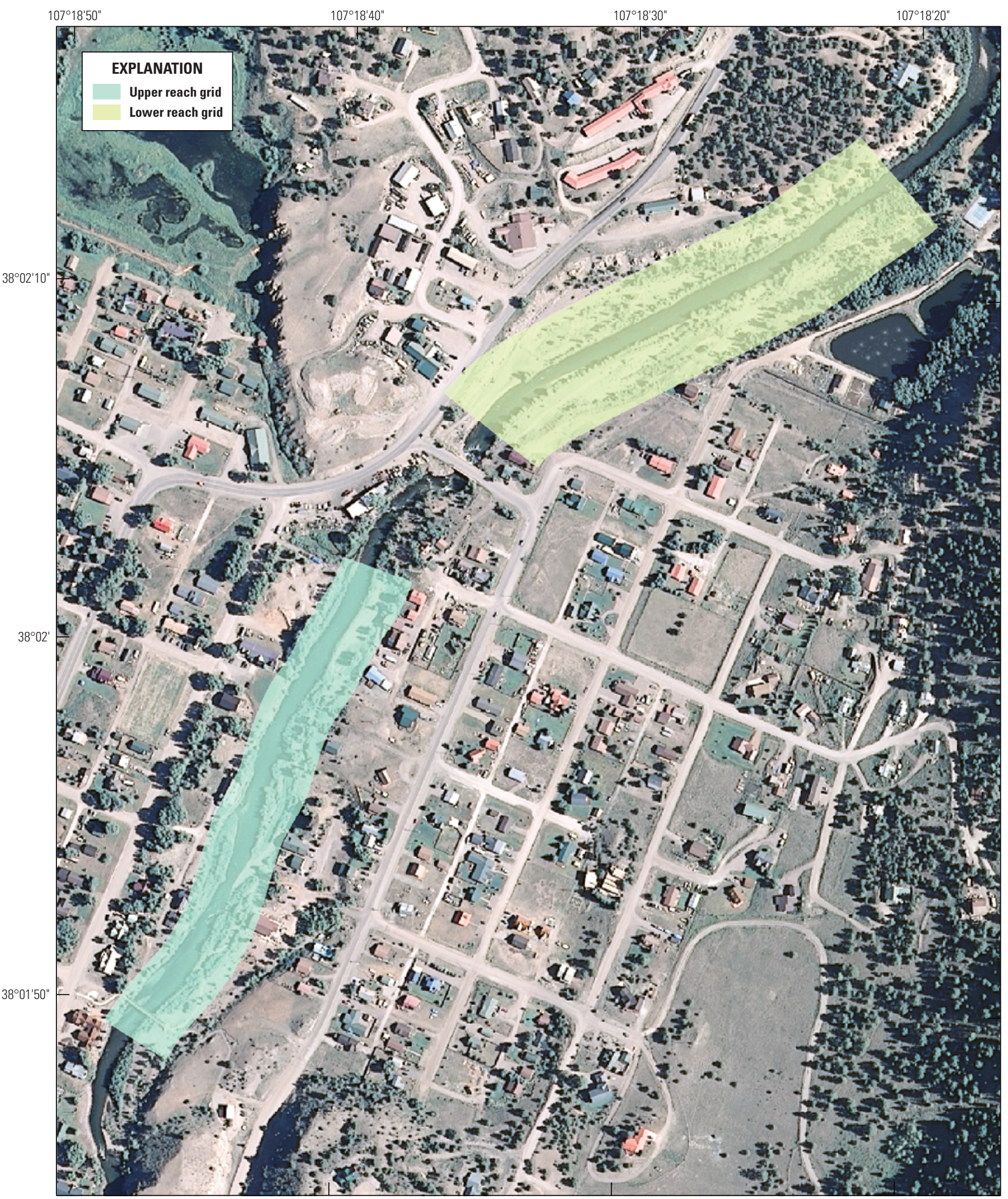

Base from U.S. Department of Agriculutre

National Agriculture Imagery Program (NAIP)

Universal Transverse Mercator Projection Zone 13 North

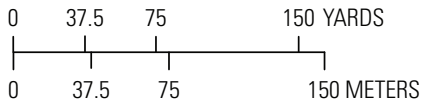

Figure 5. Map of Multidimensional Surface Water Modeling System grids of the upper and lower reaches. 

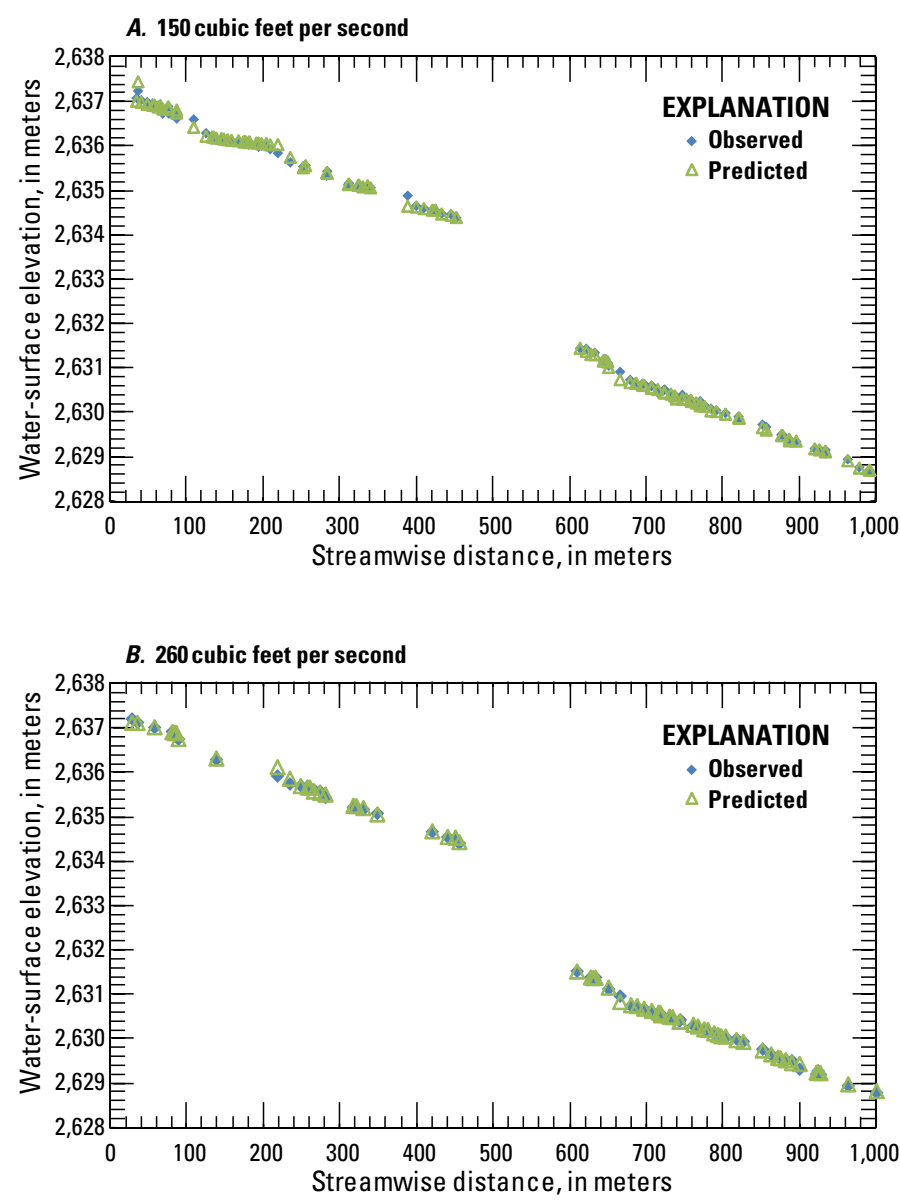

C. 1,600 cubic feet per second

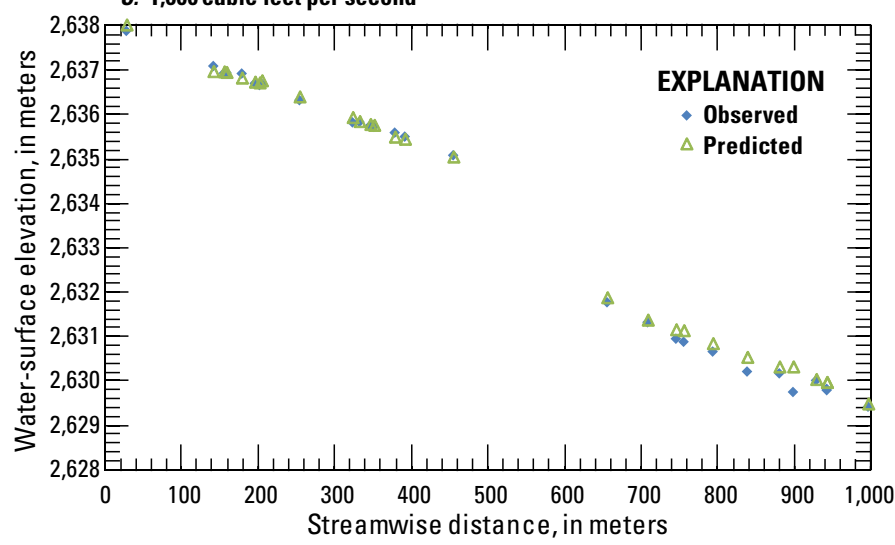

Figure 6. Graph showing water-surface elevations for the bestfit flow simulations for $A, 150$ cubic feet per second; $B, 260$ cubic feet per second; and $C, 1,600$ cubic feet per second streamflows.

study reaches. Roughness $\left(\mathrm{Z}_{0}\right)$ was varied over a range until the smallest RMSE was achieved for each flow simulation. The final value fit within the bounds of the literature values mentioned previously in this section.

\section{Sediment Mobility}

Fluvial transport of sediment particles is an important component of the assessment of channel stability. In general, sediment transport occurs within a stream when the forces acting to move a particle exceed the resisting forces of the particle. Analysis of each particle within a stream is unfeasible and dependent on the relative positioning of other particles within the stream, so a more generalized assessment of sediment mobility is presented in this report as a function of the median grain size $\left(\mathrm{d}_{50}\right)$.

In natural river systems, the portion of the boundary shear stress available to move sediment particles (grains) can be referred to as the grain shear stress (Julien, 2010). In wide, straight streams the boundary shear stress is equal to the grain shear stress. In other instances, additional energy losses reduce the shear stress available to move sediment particles. Substantial losses of energy in coarse-bed streams (gravelsized particles and larger) can be the result of turbulent eddy formation, bedforms, vegetation, and changes in channel geometry (channel expansions and contractions, alluvial bars, and meander bends). The equations within FaSTMECH, in conjunction with the computational grid density used for this analysis, inherently account for these energy losses (except those induced by vegetation). Therefore, within this analysis, the boundary shear stress estimates within the wetted channel (free of vegetation) are equal to the grain shear stress of those areas. FaSTMECH calculates boundary shear stress based on the following equation (Nelson and McDonald, 1997):

$$
\tau_{b}=\rho C d\left(u^{2}+v^{2}\right)
$$

where

$\tau_{b} \quad$ is the total boundary shear stress, in Newtons per square meter;

$\rho \quad$ is the fluid density, in kilograms per cubic meter;

$\mathrm{Cd}$ is the non-dimensional drag coefficient;

$u \quad$ is the vertically averaged stream-wise velocity, in meters per second; and

$\mathrm{v} \quad$ is the vertically averaged cross-stream velocity, in meters per second.

In order to determine the precise conditions that will result in the initiation of motion for more than one particle of interest, reasonable generalizations of the particle shape, orientation, submerged weight, and protrusion into flow must be assessed. The critical shear stress $\left(\tau_{c}\right)$ for a particle is the minimum shear stress needed for general movement of the particle to begin. Critical shear stress should be considered the minimum value for motion of the streambed because only a small fraction of the sediments will be in motion over short time periods (Milhous, 1982). Substantial mobilization of sediments has been shown to occur at roughly two times the critical shear stress (Wilcock and McArdell, 1993).

Within this report, a comparison of the boundary shear stress to critical shear stress of the median grain size $\left(d_{50}\right)$ is used to determine when sediments within the channel are 
Table 1. Summary of the lateral eddy viscosity and model diagnostics for the best-fit two-dimensional hydraulic and habitat model simulations.

[RMSE, root mean squared error; --, insufficient data]

\begin{tabular}{|c|c|c|c|c|c|}
\hline $\begin{array}{c}\text { Observed streamflow, } \\
\text { in cubic feet per } \\
\text { second }\end{array}$ & $\begin{array}{l}\text { Lateral eddy viscosity, } \\
\text { in square meters per } \\
\text { second }\end{array}$ & $\begin{array}{l}\text { RMSE for streamflow, } \\
\text { in percent }\end{array}$ & $\begin{array}{l}\text { RMSE for water- } \\
\text { surface elevation, } \\
\text { in meters }\end{array}$ & $\begin{array}{l}\text { Minimum percent } \\
\text { deviation from } \\
\text { observed streamflow }\end{array}$ & $\begin{array}{c}\text { Maximum percent } \\
\text { deviation from } \\
\text { observed streamflow }\end{array}$ \\
\hline \multicolumn{6}{|c|}{ Upper reach } \\
\hline 50 & 0.003 & 3.3 & -- & -9.0 & 12.0 \\
\hline 150 & 0.005 & 0.8 & 0.07 & -5.0 & 3.0 \\
\hline 260 & 0.005 & 0.7 & 0.06 & -3.0 & 1.0 \\
\hline 1,300 & 0.006 & 0.8 & 0.02 & -2.5 & 2.0 \\
\hline 1,600 & 0.007 & 0.8 & 0.08 & -3.5 & 2.5 \\
\hline 1,800 & 0.007 & 0.8 & 0.02 & -3.0 & 3.0 \\
\hline \multicolumn{6}{|c|}{ Lower reach } \\
\hline 50 & 0.003 & 1.1 & 0.04 & -3.0 & 8.0 \\
\hline 900 & 0.009 & 0.4 & 0.05 & -0.7 & 1.2 \\
\hline 1,300 & 0.015 & 0.2 & 0.09 & -0.4 & 0.7 \\
\hline 1,600 & 0.015 & 0.2 & 0.24 & -0.3 & 0.6 \\
\hline 1,800 & 0.015 & 0.4 & 0.06 & -1.5 & 0.6 \\
\hline
\end{tabular}

mobile. This accounts for the continuum of possible interactions of particles including hiding (conditions when mixtures of coarse and fine particles are positioned such that the finer material is sheltered by larger particles, thereby decreasing sediment mobility of the finer particles) or increased mobility (when larger particles are surrounded in a matrix of finer material, thereby increasing sediment mobility of the larger particles) (Julien, 2010).

Multiple dimensionless critical shear-stress values were selected for the sediment mobility analyses to cover the range of conditions within the reach. Based on the $\mathrm{d}_{50}$, the dimensionless critical shear stress was 0.047 using equations 2 and 3 from Julien (2010)

$$
\tau_{*_{c}} \approx 0.3 e^{\frac{-d_{*}}{3}}+0.06 \tan \varphi\left(1-e^{\frac{-d_{*}}{20}}\right)
$$

where

$\tau_{*_{c}} \quad$ is the dimensionless critical shear stress; $\phi \quad$ is the sediment particle angle of repose (assumed to be 38 degrees); and

$$
d_{*}=d_{s}\left[\frac{(G-1) g}{v_{m}^{2}}\right]^{1 / 3}
$$

where

$d_{*} \quad$ is the dimensionless sediment particle diameter;

$d_{s} \quad$ is the median grain size $\left(\mathrm{d}_{50}\right)$, in meters;

${ }_{G}^{s} \quad$ is the specific gravity of sediment $(2.65$, dimensionless); $g \quad$ is gravitational acceleration (9.81 meters per second per second); and

$v_{m} \quad$ is the kinematic viscosity at 20 degrees Celsius $\left(1.0 \times 10^{-6}\right.$ square meters per second).

A dimensionless critical shear value of 0.060 was selected to represent areas where the streambed was tightly structured or where the particles were strongly imbricated (Parker and others, 1982; Andrews, 1983; Komar, 1987; Powell and Ashworth, 1995). These two values cover a range of potential transport conditions within the stream based on field observations of streambed conditions. These values were used to estimate sediment mobility at the surveyed cross-sections.

The dimensional critical shear stress needed to initiate motion of the streambed was calculated relative to the $d_{50}$ using equation 4 . In this report, comparisons are made to the $\mathrm{d}_{50}$ within each reach. As previously mentioned, this method represents the general condition of sediment motion within the channel by accounting for occurrence of particle hiding and increased mobility of differently-sized particles.

$$
\tau_{c}=\tau_{*_{c}}\left(\gamma_{s}-\gamma\right) d_{s}
$$

$\tau_{c} \quad$ is the critical shear stress, in Newtons per square meter (pascal);

$\tau_{*_{c}} \quad$ is the dimensionless critical shear stress or Shields parameter;

$\gamma_{s} \quad$ is the specific weight of sediment $(25,996.5$ Newtons per cubic meter); 
$\gamma \quad$ is the specific weight of water $(9,810$ Newtons per cubic meter); and

$d_{s} \quad$ is the particle size of interest $\left(d_{50}\right)$, in meters. An assessment of sediment mobility was done through an assessment of transport strength using FaSTMECH. This method is most sensitive to the potential for sediment mobility because it uses the lowest threshold value for motion (dimensionless critical shear stress value of 0.03). This is a reasonable threshold accounting for conditions possibly present that were not observed in the cross-section locations. Sediment mobility is reported using equation 5 to calculate the transport strength (T), where $T=0$ is the threshold of motion and $T=1$ is the threshold for substantial motion for the $\mathrm{d}_{50}$ :

$$
T=\left(\tau_{b}-\tau_{c}\right) / \tau_{c}
$$

where
$T$ is the transport strength, dimensionless,
$\tau_{b} \quad$ is the boundary shear stress or grain shear
stress, in pascals; and
$\tau_{c} \quad$ is the critical shear stress, in pascals.

\section{Trout Habitat Suitability}

Habitat suitability was evaluated for cutthroat (Oncorhynchus clarkii) and brown trout (Salmo trutta morpha fario) fry, juveniles, and adults. These species were chosen because they represent the two extremes of trout found in Colorado mountain streams and also because they represent a comparison between native (cutthroat trout) and introduced (brown trout) salmonids in Colorado. A longitudinal stratification of these species often occurs in stream systems where multiple species of trout are present. Typically, cutthroat trout are found in headwater areas with cooler water temperatures, lower sediment concentrations, and less biological production (Hickman and Raleigh, 1982). Brown trout are usually found at the lowest reaches, where warmer water temperatures, higher sediment concentration, and higher biological production are typical (Raleigh and others, 1986).

Microscale (point locations) and mesoscale (reach features) habitat was assessed using the combination of field observations, measurements, and hydraulic simulations within the study reach of the Lake Fork. This provides resource managers with tools to assess the effects of hydrologic conditions (wet, average, and dry years) and flow alterations on habitat availability for specific streamflows or over annual timescales. To assess how habitat availability changes with streamflow, microscale-habitat quantification was done for each simulated streamflow and was also reported as a time-weighted annual total (based on typical flow frequencies).

Habitat builder in MD_SWMS was used to quantify microscale habitat availability following methodologies similar to the Habitat Suitability Index method (Hickman and Raleigh, 1982; Raleigh and others, 1986). Suitability criteria were defined based on published values for three life stages of the two fish species: (1) adult, (2) juvenile, and (3) fry, based on depth and velocity ranges (fig. 7). Habitat suitability curves, scaled from 0 to 1 , were developed for each of the three life stages based on depth and velocity conditions. A value of zero indicates that the velocity or depth condition is not acceptable; whereas a value of 1 indicates that the condition is optimal. Between 0 and 1 , habitat suitability values were interpolated linearly to indicate increasing or decreasing acceptability of the condition. For each streamflow and life stage, the habitat builder provides a map of the calculated geometric mean of the suitability curves and total weighted usable area as the sum of the area of each grid cell multiplied by the geometric mean of the grid node.

Mesoscale habitat quantification was done through the separation of each reach into features of specific habitat type (pool or riffle/run habitat) based on the geomorphology and hydraulic characteristics of larger, continuous features within each reach. Separation of these habitat types was done in a geographic information system based on velocity, depth, and visual inspection of morphological form. Separation of the reaches into two habitat types provides a comparison between the observed proportions of habitat and general guidelines derived from observations of reaches with sustained populations of each species (Hickman and Raleigh, 1982; Raleigh and others, 1986) (table 2).

A vital component of habitat for fish includes available cover. Fishes use different cover types depending on what types are available, the location of cover relative to other important habitat features (such as feeding habitat or refuge), time of year, and life stage. Cover can vary from rubble bed substrate, aquatic vegetation or plant debris, or deep pools and surface disturbances that obscure visibility from terrestrial or avian predators. Cover estimates were limited to adult life stages in this analysis. Cover estimates were quantified as a function of the distance to cover from drift feeding areas within each reach. Feeding areas were selected as areas that could provide access to food sources while requiring little exertion. These were typically lower-velocity areas adjacent to or downstream from higher velocity areas that could funnel benthic invertebrates and terrestrial insects to these fish from the current. Cover was identified as pool areas or vegetated channel banks within each reach.

\section{Two-Dimensional Hydraulic Model Sensitivity Analysis}

FaSTMECH model sensitivity was analyzed for two parameters: the lateral eddy viscosity and channel roughness based on $\mathrm{Z}_{0}$, for $150 ; 260$; and $1,600 \mathrm{ft}^{3} / \mathrm{s}$ flow simulations, because water-surface elevation data were available along the entire length of each reach for these flows. Sensitivity of the two parameters was evaluated by holding all parameters constant in best-fit flow simulations and then individually adjusting the lateral eddy viscosity and $Z_{0}$ by -25 and +25 percent. Model results from the sensitivity analysis were compared to original best-fit flow simulations (tables 3 and 4). Water-surface 

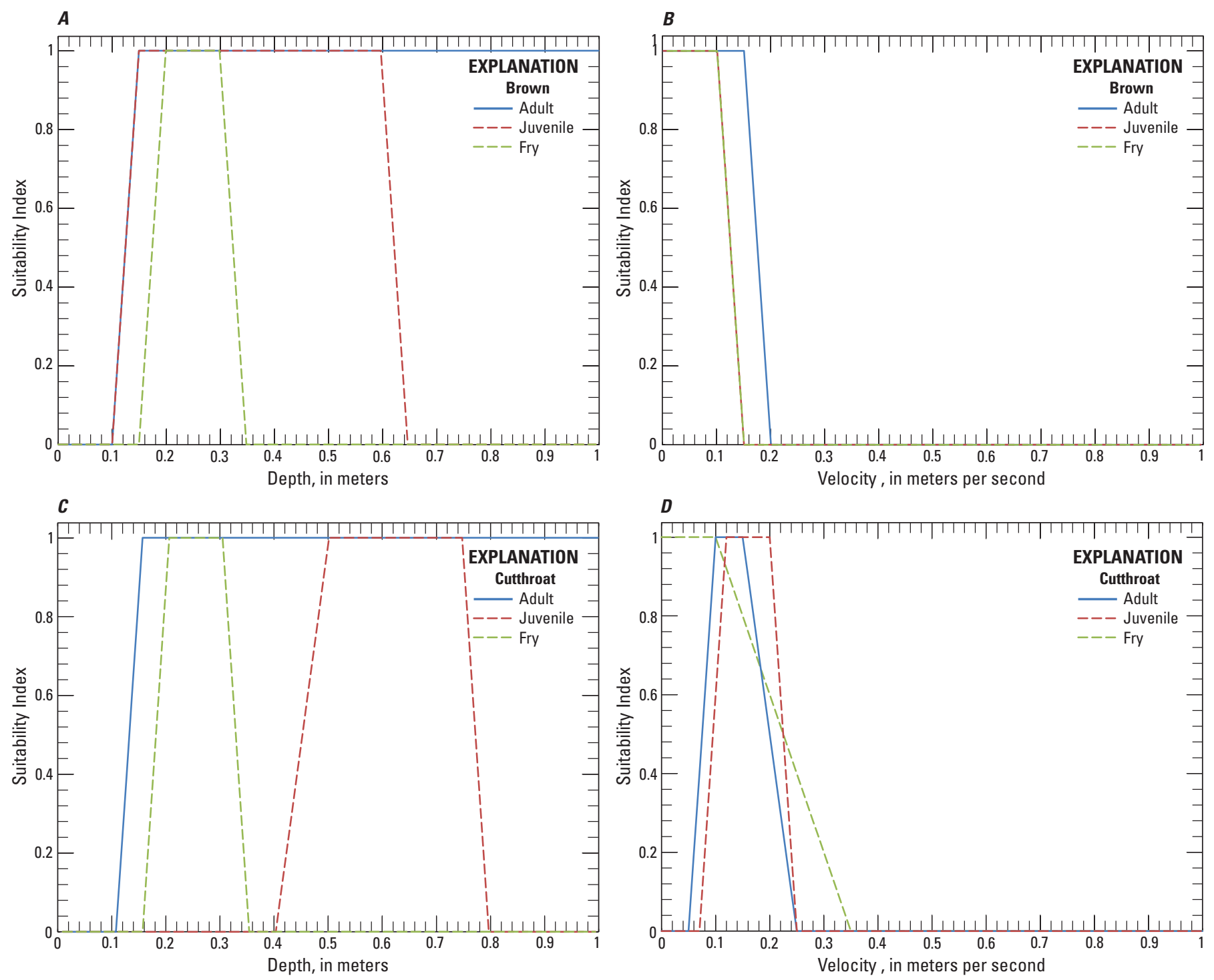

Figure 7. Habitat suitability curves for the three life stages of brown trout and cutthroat trout. $A$, habitat suitability for brown trout based on depth; $B$, habitat suitability for brown trout based on velocity; $C$, habitat suitability for cutthroat trout based on depth; $D$, habitat suitability for cutthroat trout based on velocity.

elevations, velocity, and shear stress are calculated from means of all wetted nodes in each flow simulation. Differences between the two flow simulations were reported from means of the differences in values between wetted node-pairs from each flow simulation. Percent difference was calculated as the mean difference between the two flow simulations, relative to the mean value of the best-fit flow simulation. Larger differences indicate greater sensitivity of the model parameter.

None of the flow simulations showed substantial sensitivity to changes in lateral eddy viscosity (table 3 ). The percent difference between flow simulations ranged from -0.3 percent to +0.5 percent. The extremes occurred in boundary shear stress in the lower reach for the $1,600 \mathrm{ft}^{3} / \mathrm{s}$ simulation and the upper reach for the $1,600 \mathrm{ft}^{3} / \mathrm{s}$ simulation, and in mean water-surface elevation in the upper reach for the $260 \mathrm{ft}^{3} / \mathrm{s}$ simulation. In the 1,600 $\mathrm{ft}^{3} / \mathrm{s}$ simulation at the upper reach, the +0.5 percent for mean boundary shear stress corresponded to +0.20 pascal. The largest change in mean velocity was +0.01 meters per second and the largest change in mean depth (and mean water-surface elevation) was $+0.01 \mathrm{~m}$ (table 3 ).

Flow simulations showed increased sensitivity to changes in $Z_{0}$ (table 4). Most model outputs changed by less than 10 percent. Shear stress was generally the most sensitive of model outputs, where the difference from the mean boundary shear stress ranged from -59.4 percent to +8.0 percent. Percent difference from mean velocity ranged from -1.6 to +19.5 percent; whereas, the percent difference of mean watersurface elevation ranged from -24.2 to +5.6 percent (table 4 ). 
Table 2. Mesoscale-habitat suitability ranges of habitat type for cutthroat and brown trout (from Hickman and Raleigh, 1982; Raleigh and others, 1986).

\begin{tabular}{ccc}
\hline \multirow{2}{*}{ Trout species } & \multicolumn{2}{c}{ Mesoscale habitat suitability } \\
\cline { 2 - 3 } & Pool, percent & Riffle/Run, percent \\
\hline Brown & $50-70$ & $30-50$ \\
Cutthroat & $40-60$ & $40-60$ \\
\hline
\end{tabular}

Table 3. Results from the analysis of the sensitivity of the lateral eddy viscosity parameter for three of the streamflows simulated in the multidimensional flow model for the upper and lower study reaches on the Lake Fork.

[Sensitivity analysis of the lateral eddy viscosity parameter were made at 75 (italicized values) and 125 (bolded values) percent of the calibrated lateral eddy viscosity value. Percent differences are relative to the mean of the calibrated model and percent difference in water-surface elevation is relative to the mean depth. The mean values are based on all of the wet nodes in the model. RMSE, root mean squared error; -- insufficient data]

\begin{tabular}{|c|c|c|c|c|c|c|c|c|c|}
\hline $\begin{array}{c}\text { Observed } \\
\text { streamflow, } \\
\text { in cubic } \\
\text { feet per } \\
\text { second }^{1}\end{array}$ & $\begin{array}{l}\text { Lateral eddy } \\
\text { viscosity, } \\
\text { in square } \\
\text { meters per } \\
\text { second }\end{array}$ & \multicolumn{5}{|c|}{ Model output } & \multicolumn{3}{|c|}{ Percent difference from the mean } \\
\hline \multicolumn{10}{|c|}{ Upper Reach } \\
\hline 150 & 0.008 & 0.31 & $2,635.82$ & 0.76 & 13.77 & 0.07 & -- & -- & -- \\
\hline 150 & 0.006 & 0.31 & $2,635.82$ & 0.76 & 13.77 & 0.07 & 0.3 & -0.0 & $-\mathbf{0 . 0}$ \\
\hline 260 & 0.007 & 0.38 & $2,635.92$ & 0.95 & 18.27 & 0.06 & 0.5 & 0.1 & 0.3 \\
\hline 260 & 0.006 & 0.37 & $2,635.92$ & 0.95 & 18.20 & 0.06 & -- & -- & -- \\
\hline 260 & 0.004 & 0.37 & $2,635.92$ & 0.95 & 18.19 & 0.06 & 0.1 & -0.0 & -0.1 \\
\hline 1,600 & 0.006 & 0.66 & $2,636.52$ & 1.52 & 32.29 & 0.08 & -0.1 & 0.1 & 0.5 \\
\hline 150 & 0.002 & 0.30 & $2,629.96$ & 0.78 & 17.52 & 0.04 & -0.0 & -0.0 & -0.0 \\
\hline 150 & 0.002 & 0.30 & $2,629.96$ & 0.78 & 17.52 & 0.04 & -- & -- & -- \\
\hline 150 & 0.003 & 0.30 & 2,629.96 & 0.78 & 17.51 & 0.04 & $\mathbf{0 . 0}$ & -0.0 & -0.1 \\
\hline 260 & 0.004 & 0.38 & $2,630.06$ & 0.99 & 21.87 & 0.04 & -0.1 & -0.0 & -0.1 \\
\hline 260 & 0.005 & 0.38 & $2,630.06$ & 0.99 & 21.89 & 0.04 & -- & -- & -- \\
\hline 260 & 0.006 & 0.38 & $2,630.06$ & 0.99 & 21.85 & 0.04 & 0.0 & -0.0 & -0.2 \\
\hline 1,600 & 0.011 & 0.94 & $2,630.74$ & 1.93 & 54.69 & 0.24 & -0.0 & 0.0 & 0.1 \\
\hline 1,600 & 0.015 & 0.94 & $2,630.74$ & 1.93 & 54.61 & 0.24 & -- & -- & -- \\
\hline 1,600 & 0.019 & 0.94 & $2,630.75$ & 1.92 & 54.48 & 0.24 & 0.1 & -0.0 & -0.3 \\
\hline
\end{tabular}

${ }^{1}$ To convert from cubic feet per second to cubic meters per second divide by 35.31 . 
Table 4. Results from the analysis of the sensitivity of the roughness parameter $\left(Z_{0}\right)$ for three of the streamflows simulated in the twodimensional flow model for the upper and lower study reaches on the Lake Fork.

[Sensitivity analysis of the roughness parameter $\left(Z_{0}\right)$ were made at 75 (italicized values) and 125 (bolded values) percent of the calibrated $Z_{0}$ value. Percent differences are relative to the mean of the calibrated model and percent difference in water surface elevation is relative to the mean depth. The mean values are based on all of the wet nodes in the model. RMSE, root mean squared error; -- insufficient data]

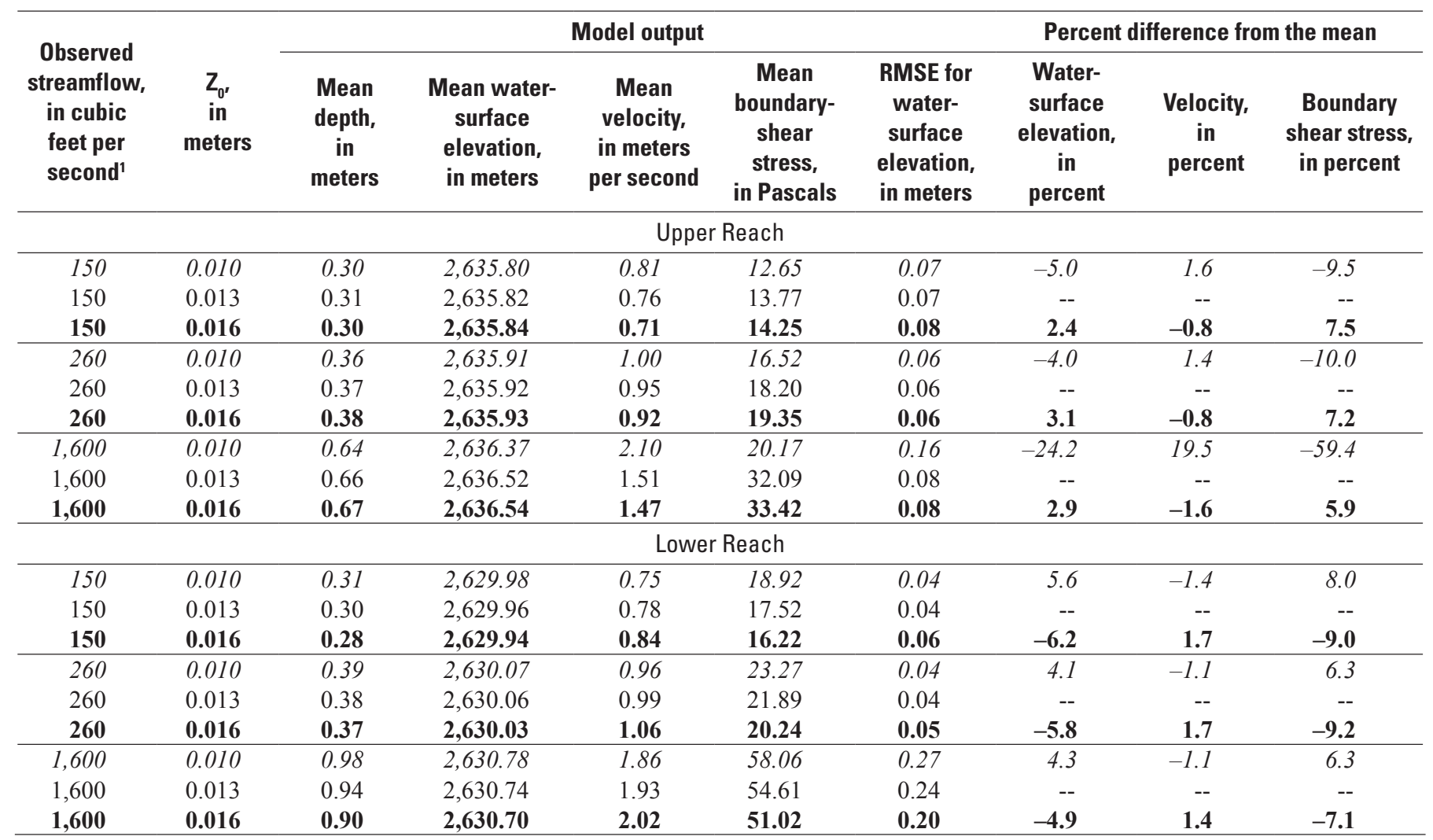

${ }^{1}$ To convert from cubic feet per second to cubic meters per second divide by 35.31 . 


\section{Hydraulic and Geomorphic Conditions}

The existing hydraulic and geomorphic conditions for a 1.1-km section of the Lake Fork at Lake City are summarized as a function of the current streamflow regime based on model simulations for eight streamflows that cover the range of streamflow conditions typically observed at the site (figs. 2 and 8). Comparisons and evaluation of differences in sediment mobility and habitat suitability will provide resource managers with information to evaluate existing channel stability and habitat conditions of the reach as well as provide a baseline to compare with future conditions.

Within these systems, limiting fine-sediment deposition and removal of fine sediments (sizes less than 2 millimeters $[\mathrm{mm}]$ ) within framework grain interstitial spaces enhances habitat suitability for both fish and invertebrates. Gravel substrates used for spawning redds (spawning habitat) are most suitable when free of finer sediments (Hickman and Raleigh, 1982; Raleigh and others, 1986). Benthic invertebrates productivity and abundance, as well as larval and fry refugia, are optimized when fine sediments are limited to less than 5 percent (Hickman and Raleigh, 1982; Raleigh and others, 1986). Sediment mobility is an important process for flushing fine sediments from within the gravel frameworks.

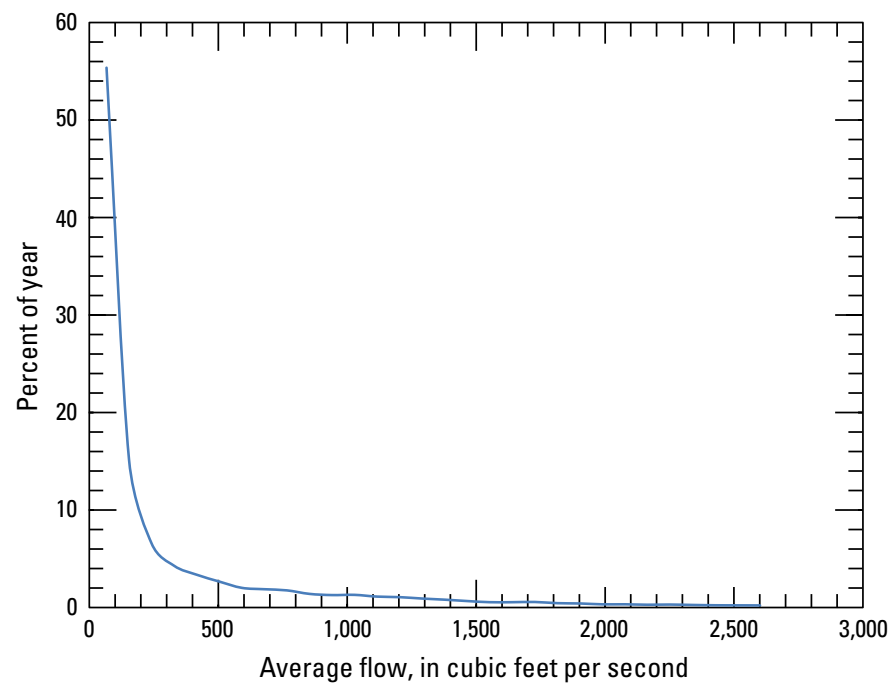

Figure 8. Flow frequency curve for the Lake Fork of the Gunnison River at Lake City, Colorado.

\section{Sediment Mobility}

Boundary shear stress calculated from each flow simulation was compared to the critical shear stress of mean $d_{50}$ in each reach to determine streambed mobility (fig. 9 and table 5). In this report, where boundary shear stress was equal to critical shear, sediment transport conditions are reported as potentially mobile; where the boundary shear stress exceeded two times the critical shear stress, sediment transport conditions are reported as substantially mobile.

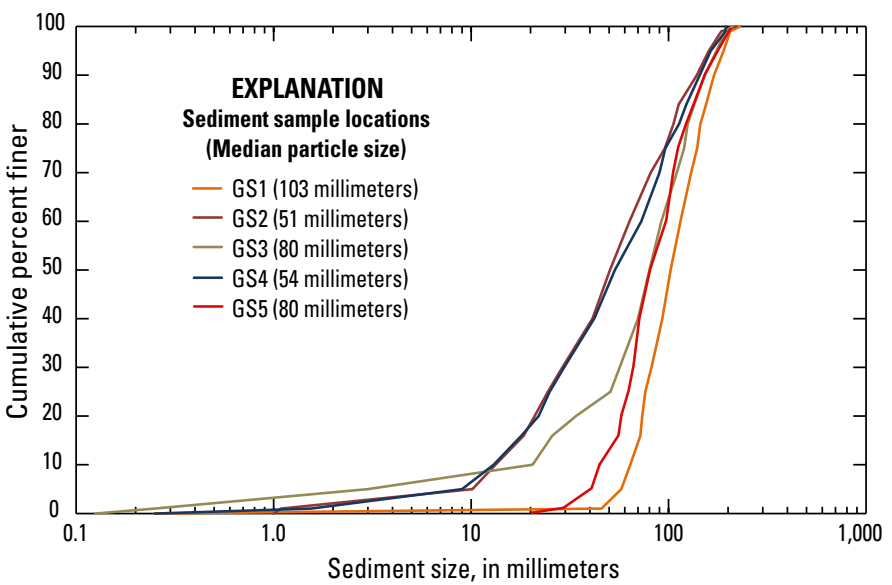

Figure 9. Sediment-size characteristics of the five sampling sites.

Table 5. Sediment particle-size characteristics for the five sites sampled from August 4 to August 6, 2010, and August 18, 2011 (GS1-GS4 and GS-5, respectively) in the Lake Fork study area. (Grain-size sample locations [GS1-GS5] are shown in fig. 3.)

[Easting and Northing datum is Universal Transverse Mercator Zone 13 North American Datum 1983; $\mathrm{d}_{50}$, median (50th percentile) particle diameter; $\mathrm{d}_{84}, 84$ th percentile particle diameter]

\begin{tabular}{|c|c|c|c|c|}
\hline $\begin{array}{l}\text { Site short } \\
\text { name }\end{array}$ & $\begin{array}{l}\text { Easting, } \\
\text { in meters }\end{array}$ & $\begin{array}{l}\text { Northing, } \\
\text { in meters }\end{array}$ & $\begin{array}{c}\mathrm{d}_{50^{\prime}} \\
\text { in } \\
\text { millimeters }\end{array}$ & $\begin{array}{c}\mathrm{d}_{84^{\prime}} \\
\text { in } \\
\text { millimeters }\end{array}$ \\
\hline GS1 & 296,993 & $4,211,721$ & 103 & 155 \\
\hline GS2 & 297,083 & $4,211,874$ & 51 & 113 \\
\hline GS3 & 297,172 & $4,212,064$ & 80 & 135 \\
\hline \multicolumn{3}{|c|}{ Upper reach average } & 78 & 134 \\
\hline GS4 & 297,358 & $4,212,262$ & 54 & 123 \\
\hline GS5 & 297,476 & $4,212,329$ & 80 & 132 \\
\hline \multicolumn{3}{|c|}{ Lower reach average } & 67 & 128 \\
\hline
\end{tabular}

Evaluations of channel and flow characteristics at crosssection locations $2-8$, presented in downstream order, show a range of streambed mobility (figs. 10 and 11). In general, boundary shear stress and streambed mobility increase with increases in streamflow. At streamflows of 50, 150, and 260 $\mathrm{ft}^{3} / \mathrm{s}$ the streambed is not mobile (figs. 10 and 11). However, the streambed is potentially mobile for the $400 \mathrm{ft}^{3} / \mathrm{s}$ streamflow at cross-sections 4-8 depending on which dimensionless critical-shear stress value is referenced $(0.03,0.047$, or 0.06$)$ (figs. 10 and 11). At cross sections $2-8$, sediment is potentially mobile at streamflows of $900 \mathrm{ft}^{3} / \mathrm{s}$. The streambed is substantially mobile at cross sections $4-8$ at streamflows of 1,300 to $1,600 \mathrm{ft}^{3} / \mathrm{s}$ with all cross sections being substantially mobile at $1,800 \mathrm{ft}^{3} / \mathrm{s}$ (figs. 10-11). Within the cross sections, the greatest boundary shear stress occurs towards the center of the channel. Sediments are generally less mobile near the channel margins for all flow simulations. 

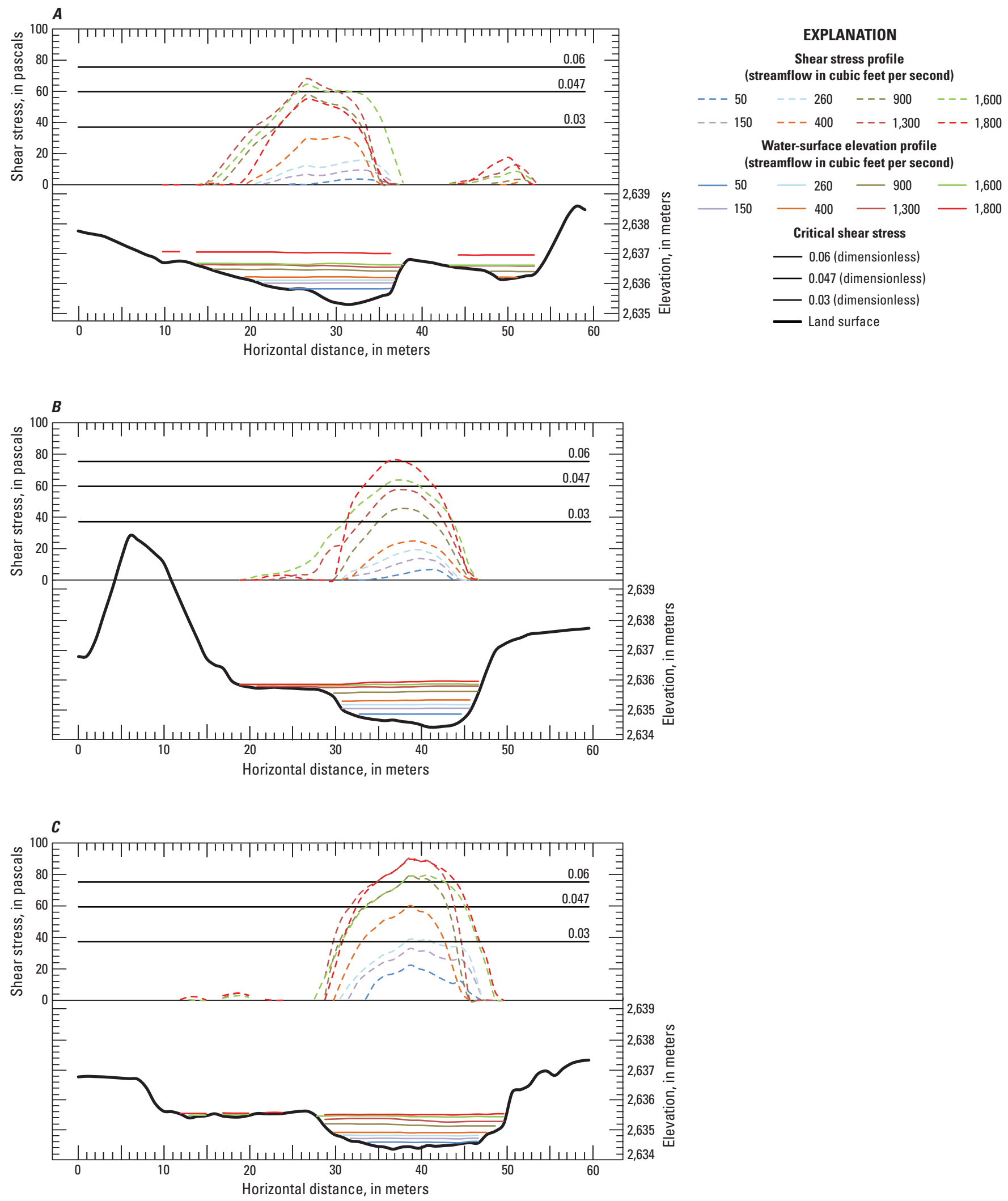

Figure 10. Shear stress and water-surface elevation plots at $A$, cross-section $2 ; B$, cross-section 3 ; and $C$, cross-section 4. 

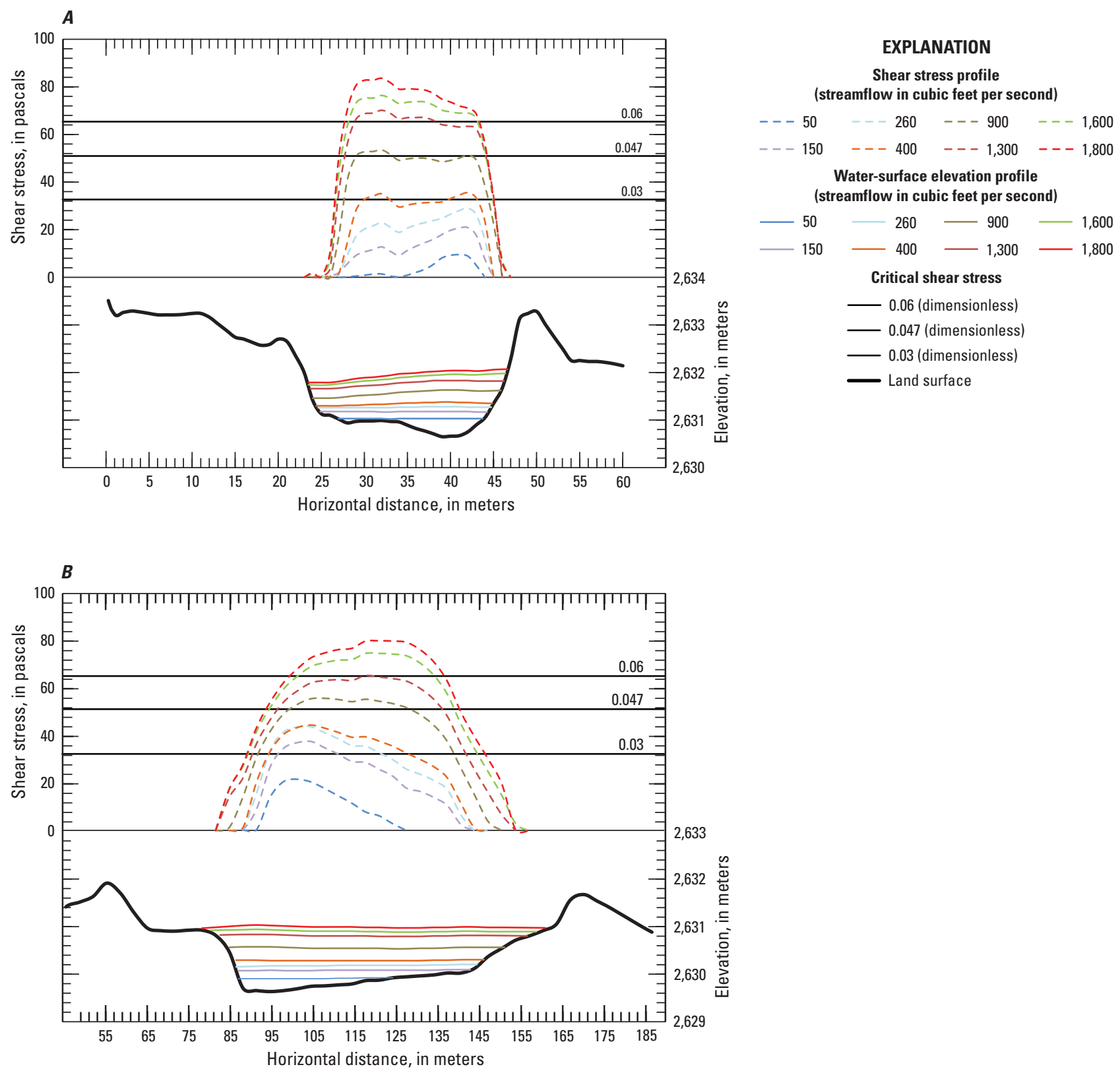

Figure 11. Shear stress and water-surface elevation plots at $A$, cross-section $5 ; B$, cross-section $6 ; C$, cross-section 7 ; and $D$, cross-section 8 . 

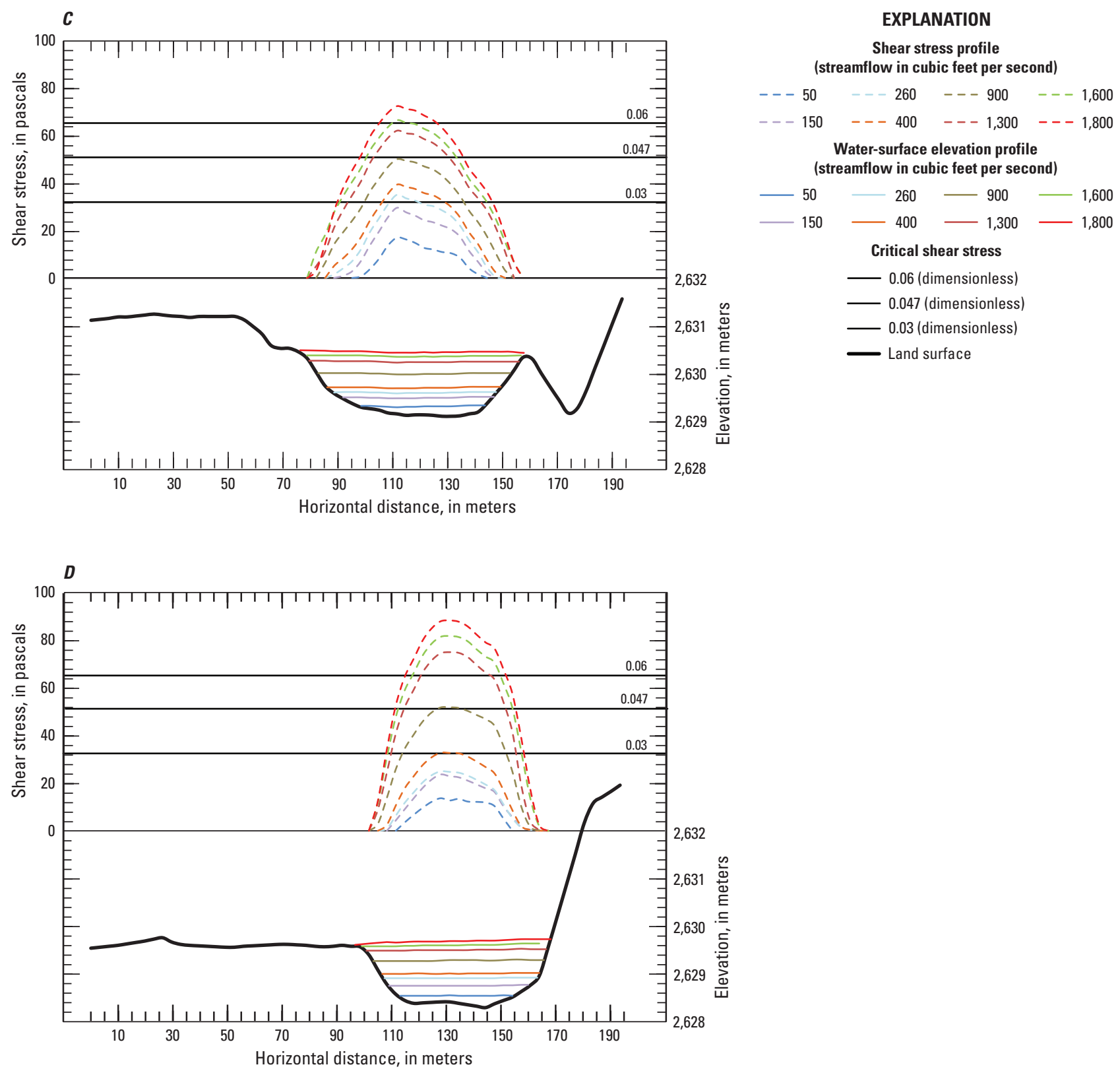

Figure 11. Shear stress and water-surface elevation plots at $A$, cross-section $5 ; B$, cross-section $6 ; C$, cross-section 7 ; and $D$, cross-section 8.-Continued

Reach-scale assessment of sediment mobility in the upper reach shows that there are areas where the streambed is potentially mobile for all streamflow simulations and that boundary shear stress and streambed mobility increase as streamflow increases (fig. $12 A-C$ ). For streamflows of $400 \mathrm{ft}^{3} / \mathrm{s}$ or less, the streambed is potentially mobile in some areas. Areas where the streambed is substantially mobile began to appear in flow simulations of $900 \mathrm{ft}^{3} / \mathrm{s}$ and greater, and the size of these areas increase as streamflow increases. At streamflows of $1,300 \mathrm{ft}^{3} / \mathrm{s}$ or greater, the majority of the channel is potentially mobile except areas along the channel margins.
Reach-scale assessment of sediment mobility in the lower reach shows increased streambed mobility (fig. 12D-F). This is due in part to smaller grain sizes in the lower reach (mean $\mathrm{d}_{50}$ is $11 \mathrm{~mm}$ smaller than the upper reach mean $\mathrm{d}_{50}$, [table 5]) but may also reflect the greater extent of channel

Figure 12. Reach-scale assessment of sediment mobility in the upper reach $(A-C)$ and lower reach $(D-F)$ of the Lake Fork of the Gunnison River at streamflows of 400; 900; and 1,800 ft3/s, respectively.-Following page 

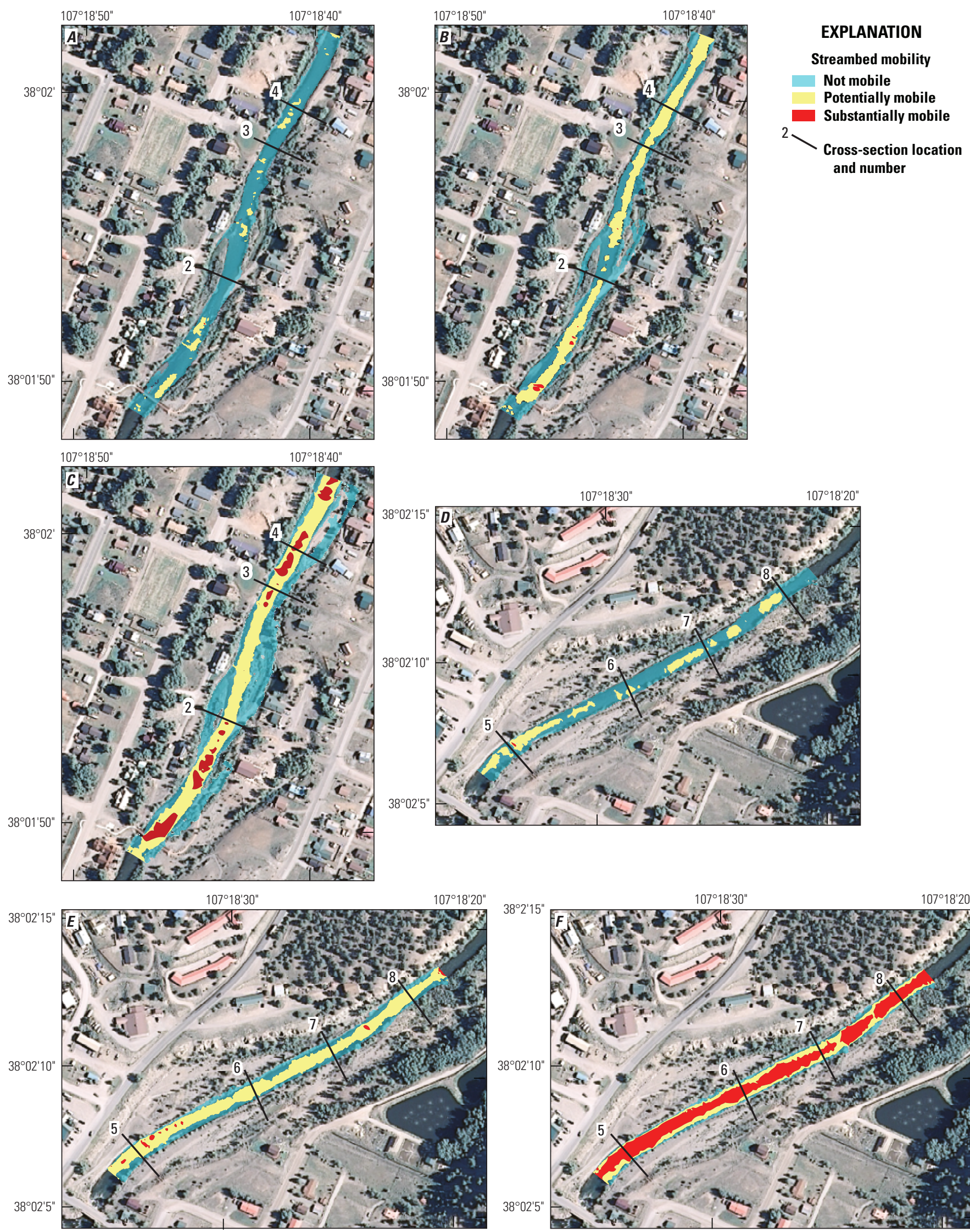

Base from U.S. Department of Agriculutre

National Agriculture Imagery Program (NAIP)

Universal Transverse Mercator Projection Zone 13 North

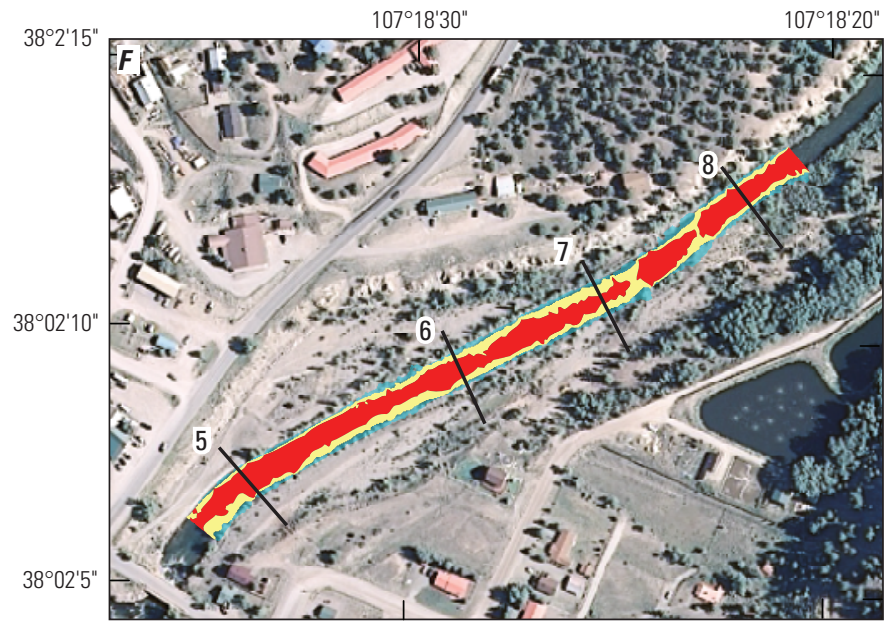


alterations, specifically the temporary berms constructed by CDOT in the late 1980s and early 1990s, present in this reach. In the $400 \mathrm{ft}^{3} / \mathrm{s}$ flow simulation, some areas within the channel become substantially mobile with additional areas of potential mobility appearing downstream throughout the reach. In the $900 \mathrm{ft}^{3} / \mathrm{s}$ flow simulation, the entire length of the channel becomes potentially mobile with small patches of the streambed that are substantially mobile. In the $1,800 \mathrm{ft}^{3} / \mathrm{s}$ flow simulation, the majority of the channel along its entire length is substantially mobile except along the channel margins which are potentially mobile.

\section{Geomorphic Channel Form}

Geomorphic channel form is affected by land-use changes within the basin and geologic controls within the reach (Lake Fork Valley Conservancy, 2010). The historic channel was defined as a dynamic, braided channel (multiple, bifurcating channels) with an active flood plain (Lake Fork Valley Conservancy, 2010). Comparisons of the channel slope, high-flow conditions, or floods (Capesius and Stephens, 2009; U.S. Geological Survey, 2010b), and $d_{50}$ of each reach to channel-form thresholds (meandering and braided channel) indicated that current channel characteristics may favor a braided channel form (fig. 13) (Leopold and Wolman, 1957; Richards, 1982). This can result in a natural tendency for the channel to braid, which can affect channel stability of reconfigured reaches when a single-thread meandering channel is imposed on the stream (Elliott and Capesius, 2009). The similarities of channel slope, total stream power index (streamflow times channel slope), and median bed-material size for the upper and lower reaches and at Gateview, which was historically a braided reach and is considered a reference reach for this report, support a natural tendency for the channels to braid in both reaches (fig. 13).

Additional constraints on channel form include natural and artificial impingement of the active channel occurring from placement of boulder revetments, cobble-boulder berms, and bedrock outcrops along the channel margins. Boulder revetments are common between cross-sections 1 and 5 along the left bank of the river, with limited use along the right bank. Cobble-boulder berms occur between cross-sections 4 and 8 along both banks. Bedrock constraints occur along both banks for much of the channel between cross-sections 4 and 5, and along the left bank between cross-sections 6 and 8 . These features constrain the channel from lateral migration and channel adjustments and potentially limit the capability of geomorphic channel response to alterations in this area.

\section{Trout Habitat Characteristics}

Habitat suitability analysis can include an evaluation of several inter-related stream conditions (Bovee, 1982). Dissolved oxygen, water temperature, $\mathrm{pH}$, and other waterchemistry constituents (nutrients, metals, and total dissolved solids) are important to overall aquatic habitat suitability; however, this analysis will focus on the physical habitat elements of the reach such as depth, velocity, and distance to cover. Model output for each streamflow was used to quantify trout habitat abundance.

\section{Microscale Trout Habitat}

Microscale trout habitat, defined as weighted-usable area, generally increased as streamflow increased for both trout species and all life stages (fig. 14). Areas of suitable microscale habitat occur along the banks for flows of $900 \mathrm{ft}^{3} / \mathrm{s}$ and less. Out-of-bank areas contributed more substantially to overall habitat availability for flows of $1,300 \mathrm{ft}^{3} / \mathrm{s}$ or more when compared to other features. Adult habitat, for both trout species, was the most abundant habitat type for nearly all streamflows. Habitat for juvenile cutthroat trout and brown trout fry was the least abundant in both reaches. In general, the upper reach provided 2-3 times more available habitat than the lower reach for both trout species.

In order to determine the interaction of flow frequency and habitat abundance within the current flow regime, a combination of the available habitat was related to the probability of that flow occurring each year. This relation provides a measure of the overall habitat for each life stage over the course of an average flow year. The results are summarized by species and life stage in table 6 .

There are seasonal differences between the two species when fry are present in the stream (Hickman and Raleigh, 1982; Raleigh and others, 1986). Both species construct redds when spawning in small gravelly areas with good hyporheic flows and minimal fine sediments. However, cutthroat trout do so in early spring (February or later, based on water temperatures) and the larvae typically hatch within 28-49 days depending on water temperatures (Hickman and Raleigh, 1982). Brown trout construct redds in late summer to early fall; this makes the redds more susceptible to over-wintering conditions within the gravels and possible smothering due to fine sediment deposition (Raleigh and others, 1986). However, when brown trout emerge in the spring they are larger and typically better able to out-compete cutthroat fry if resources are limited (Raleigh and others, 1986). The flows that typically occur during these two different time periods were used to calculate the total weighted-usable habitat in a typical year for the fry of both species (table 6).

\section{Mesoscale Trout Habitat}

Mesoscale trout habitat assessment of the Lake Fork was done based on the conditions present in the $150 \mathrm{ft}^{3} / \mathrm{s}$ flow simulation as well as field observation. Both the upper and lower reaches are primarily characterized as riffle/run habitat; however, in the upper reach, the total available pool habitat (total wetted area) is greater (table 7). The presence of pool habitat was limited throughout both reaches and occurred along the channel margins. For both reaches, the pool habitat was less 

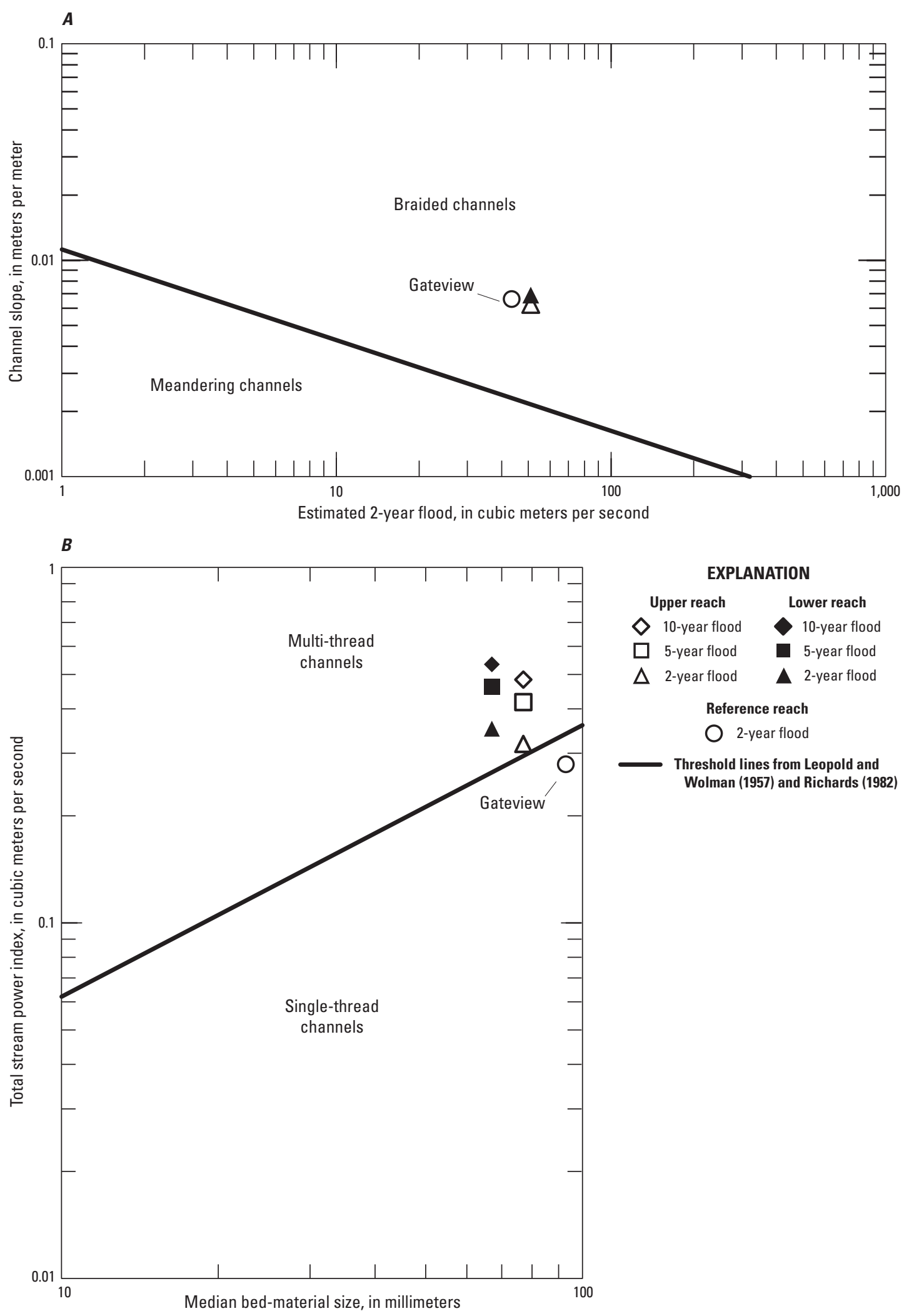

EXPLANATION

\begin{tabular}{|c|c|}
\hline Upper reach & Lower reach \\
\hline$\diamond 10$-year flood & 10-year flood \\
\hline 5-year flood & 5-year flood \\
\hline$\Delta$ 2-year flood & 2-year flood \\
\hline
\end{tabular}

Reference reach

2-year flood

Threshold lines from Leopold and Wolman (1957) and Richards (1982)

Figure 13. Plotting positions of two surveyed reaches of the Lake Fork of the Gunnison River near Lake City, Colorado, in comparison to thresholds for meandering and braided channel patterns based on findings from $A$, Leopold and Wolman (1957) and $B$, Richards (1982). 


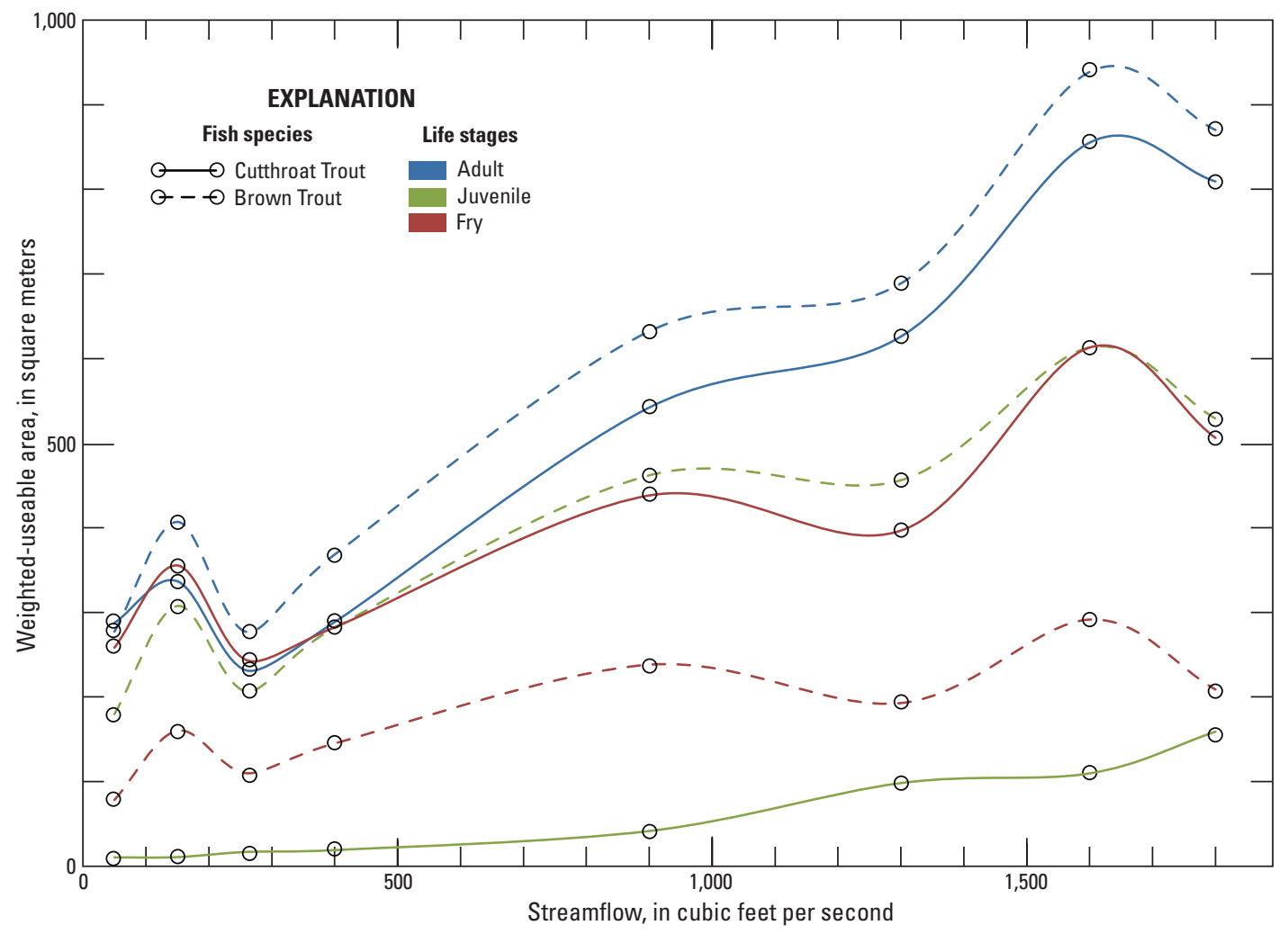

Figure 14. Weighted-usable habitat for the adult, juvenile, and fry life stages of the cutthroat and brown trout in the study reach of the Lake Fork of the Gunnison River.

Table 6. Results from flow-frequency curves and simulation results from the multidimensional flow model showing microscale-habitat suitability total weighted-useable habitat in a typical year for cutthroat and brown trout.

\begin{tabular}{cccc}
\hline \multirow{2}{*}{ Trout species } & \multicolumn{3}{c}{ Life stage } \\
\cline { 2 - 4 } & $\begin{array}{c}\text { Adult } \\
\text { square meters }\end{array}$ & $\begin{array}{c}\text { Juvenile } \\
\text { square meters }\end{array}$ & $\begin{array}{c}\text { Fry } \\
\text { square meters }\end{array}$ \\
\hline Brown & 358 & 249 & 96 \\
Cutthroat & 332 & 19 & 279 \\
\hline
\end{tabular}

Table 7. Mesoscale-habitat characteristics for cutthroat and brown trout during typical baseflow conditions in the Lake Fork near Lake City, Colorado.

\begin{tabular}{cccccc}
\hline Reach & $\begin{array}{c}\text { Total wetted area, } \\
\text { in square meters }\end{array}$ & $\begin{array}{c}\text { Pool area, } \\
\text { in square meters }\end{array}$ & $\begin{array}{c}\text { Pool, } \\
\text { in percent }\end{array}$ & $\begin{array}{c}\text { Riffle/Run, } \\
\text { in percent }\end{array}$ & $\begin{array}{c}\text { Distance to cover } \\
\text { from feeding areas, } \\
\text { in meters }\end{array}$ \\
\hline Upper & 7,126 & 315 & 4.4 & 95.6 & 15 \\
Lower & 6,231 & 47 & 0.7 & 99.3 & less than 1 \\
\hline
\end{tabular}


than 5 percent of the total wetted area. This percentage is substantially lower than the recommendations for sustainable populations of 40-70 percent (tables 2 and 7) (Hickman and Raleigh, 1982; Raleigh and others, 1986). An exception to this is an isolated scour pool located outside of the modeled area (between the two reaches) below a waterfall which was not quantified in this analysis.

Riparian canopy study results show differences between the upper and lower reaches. Riparian canopy density measurements were consistent in the upper reach, with approximately 20 percent coverage occurring along both banks throughout (fig. 4). Vegetation patterns in the lower reach were less consistent and demonstrate local effects of topography. The large hillslope along the left bank between cross-sections 7 and 8 produced greater canopy density and shading than other areas (fig. 4).

Assessment of the distance of various in-stream habitats to cover (pool areas or vegetated channel banks within each reach) from potential feeding areas shows differences between the characteristics of the two reaches. Areas of cover were adjacent to potential drift feeding areas in the lower reach, and often occurred within the same pool habitat (distance to cover from feeding areas were less than $1 \mathrm{~m}$ ). This condition may favor energy expenditure ratios of both fish species, wherein little energy is needed to acquire adequate food sources (table 7). In the upper reach, distances from drift feeding areas to cover were much greater $(15 \mathrm{~m})$, a condition that is less conducive to cutthroat trout which tend to occupy drift feeding areas where cover is located nearby (Hickman and Raleigh, 1982).

\section{Summary}

Since the 1950s, the Lake Fork of the Gunnison River has been an area of active channel modification to accommodate the needs of the Lake City community. The Lake Fork Valley Conservancy District began a planning process to assess restoration options for a reach of the Lake Fork in Lake City to enhance hydraulic and ecologic characteristics of the reach.

Channel rehabilitation, or reconfiguration, to mitigate a variety of riverine problems has become a common practice in the western United States. Reasons for channel rehabilitation include restoration to more natural or historical conditions, improved water conveyance in flood-prone areas, mitigation of unstable streambeds and streambanks, increased sediment transport, enhancement of aquatic and riparian habitat, improved water quality, and recreation. Numerous private entities and resource-management agencies have attempted to modify stream channels by using designs based on different geomorphic philosophies and classification schemes. However, additional work to monitor and assess the channel response to, and the effectiveness of, these modifications over longer periods of time (decadal or longer) is still needed. To address this need, the U.S. Geological Survey is engaged in a program designed to monitor and assess selected river reaches that have undergone reconfiguration. The U.S. Geological Survey, in cooperation with the Colorado Water Conservation Board and Colorado River Water Conservation District, began a study in 2010 to quantify existing hydraulic and habitat conditions for a reach of the Lake Fork of the Gunnison River in Lake City, Colorado.

The purpose of this report is to quantify existing Lake Fork hydraulic and habitat conditions and establish a baseline against which post-reconfiguration conditions can be compared. This report (1) quantifies the existing hydraulic and geomorphic conditions in a 1.1-km section of the Lake Fork at Lake City that has been proposed as a location for future channel-rehabilitation efforts, (2) characterizes the habitat suitability of the reach for two trout species based on physical conditions within the stream, and (3) characterizes the current riparian canopy density. This characterization describes existing channel conditions and establishes a baseline for postreconfiguration comparisons for resource managers to evaluate restoration project success.

Sediment particles were measured at five locations in the study reach to characterize the grain size of different geomorphic surfaces and to estimate channel roughness. Bars and channel margins were chosen because these areas are inundated most of the year and represent the coarser material transported within the river channel.

Canopy density was characterized during a low-flow period at multiple locations within the study area using a spherical densiometer. Differences in canopy density can affect water temperatures, terrestrial insect and leafy organic inputs into the aquatic system, and habitat cover. Four measurements were taken at each location from the center of the stream with the operator facing: upstream, downstream, towards left bank, and towards right bank.

The FaSTMECH computational flow-model within MD_SWMS was selected to characterize the effects of streamflow on hydraulic and habitat-suitability conditions for the 1.1-km study reach of the Lake Fork. Channel geometry was obtained from the topographical survey of the channel. Model calibration was achieved through iterative adjustments of the roughness until the root mean squared error between the observed and simulated water-surface elevations was minimized.

Within this report, a comparison of the boundary shear stress to critical shear stress of the median grain size $\left(\mathrm{d}_{50}\right)$ is used to determine when sediments within the channel are mobile. Multiple dimensionless critical shear-stress values were selected for the sediment mobility analyses to cover the range of conditions within the reach (dimensionless critical shear-stress values of 0.047 and 0.060). An assessment of sediment mobility was done through an assessment of transport strength using FaSTMECH.

Habitat suitability was evaluated for cutthroat (Oncorhynchus clarkii) and brown trout (Salmo trutta morpha fario) fry, juveniles, and adults. These species were chosen because they represent the two extremes of trout found in Colorado mountain streams and also because they represent a comparison between native (cutthroat trout) and introduced (brown 
trout) salmonids in Colorado. Microscale (point locations) and mesoscale (reach features) habitat was assessed using the combination of field observations, measurements, and hydraulic simulations within the study reach of the Lake Fork.

FaSTMECH model sensitivity was analyzed for two parameters: the lateral eddy viscosity and channel roughness based on $\mathrm{Z}_{0}$, for $150 ; 260$; and $1,600 \mathrm{ft}^{3} / \mathrm{s}$ flow simulations, because water-surface elevation data were available along the entire length of each reach for these flows. Shear stress was generally the most sensitive of model outputs, where the difference from the mean boundary shear stress ranged from -59.4 percent to +8.0 percent. Percent difference from mean velocity ranged from -1.6 to +19.5 percent, whereas the percent difference of mean water-surface elevation ranged from -24.2 to +5.6 percent.

The existing hydraulic and geomorphic conditions for a 1.1-km section of the Lake Fork at Lake City are summarized as a function of the current streamflow regime based on model simulations for eight streamflows that cover the range of streamflow conditions typically observed at the site. Comparisons and evaluation of differences in sediment mobility and habitat suitability will provide resource managers with information to evaluate existing channel stability and habitat conditions of the reach as well as provide a baseline to compare with future conditions.

Within these systems, limiting fine sediment deposition and removal of fine sediments (sizes less than $2 \mathrm{~mm}$ ) within framework grain interstitial spaces enhances habitat suitability for both fish and invertebrates. Sediment mobility is an important process for flushing fine sediments from within the gravel frameworks. Evaluations of channel and flow characteristics at cross-section locations 2-8 show a range of streambed mobility. In general, boundary shear stress and streambed mobility increase with increases in streamflow. At cross sections 2-8, sediment is potentially mobile at streamflows of $900 \mathrm{ft}^{3} / \mathrm{s}$. The streambed is substantially mobile at cross sections $4-8$ at streamflows of 1,300 to $1,600 \mathrm{ft}^{3} / \mathrm{s}$ with all cross sections being substantially mobile at $1,800 \mathrm{ft}^{3} / \mathrm{s}$. Within the cross sections, the greatest boundary shear stress occurs towards the center of the channel. Reach-scale assessment of sediment mobility in the lower reach shows increased streambed mobility. This is due in part to smaller grain sizes in the lower reach but may also reflect the greater extent of channel alterations, specifically the temporary berms constructed by CDOT in the late 1980s and early 1990s, present in this reach.

Geomorphic channel form is affected by land-use changes within the basin and geologic controls within the reach. The historic channel was defined as a dynamic, braided channel with an active flood plain. Comparisons of the channel characteristics to channel-form thresholds indicated that current channel characteristics may favor a braided channel form. This can result in a natural tendency for the channel to braid, which can affect channel stability of reconfigured reaches when a single-thread meandering channel is imposed on the stream.

Microscale trout habitat, presented as weighted usable area, generally increased as streamflow increased for both trout species and all life stages. Areas of suitable microscale habitat occur along the banks for flows of $900 \mathrm{ft}^{3} / \mathrm{s}$ and less. Out-of-bank areas become more substantial contributors to overall habitat availability for flows of $1,300 \mathrm{ft}^{3} / \mathrm{s}$ or more when compared to other features. Adult habitat, for both trout species, was the most abundant habitat type for nearly all streamflows. In general, the upper reach provided 2-3 times more available habitat than the lower reach for both trout species.

Mesoscale trout habitat assessment of the Lake Fork was done based on the conditions present in the $150 \mathrm{ft}^{3} / \mathrm{s}$ flow simulation as well as field observation. Both the upper and lower reaches are primarily characterized as riffle/run habitat. The presence of pool habitat was limited throughout both reaches and occurred along the channel margins. For both reaches, the pool habitat was less than 5 percent of the total wetted area, a percentage that is substantially lower than the recommendations for sustainable populations of 40-70 percent. An exception to this is an isolated scour pool located outside of the modeled area (between the two reaches) below a waterfall which was not quantified in this analysis. Areas of cover were adjacent to potential drift feeding areas in the lower reach, and often occurred within the same pool habitat. This may favor energy expenditure ratios of both fish species, wherein little energy is needed to acquire adequate food sources.

\section{References Cited}

Andrews, E.D., 1983, Entrainment of gravel from naturally sorted riverbed material: Geological Society of America Bulletin, v. 94, p. 1225-1231.

Barnes, H.H. Jr., 1977, Roughness characteristics of natural channels: U.S. Geological Survey Water-Supply Paper $1849,213 \mathrm{p}$.

Bovee, K.D., 1982, A guide to stream habitat analysis using the Instream Flow Incremental Methodology-Instream flow information Paper 12: U.S. Fish and Wildlife Service, Office of Biological Services, FS/OBS-82/26, 249 p.

Bray, D.I., 1982, Flow resistance in gravel-bed rivers, in Hey, R.D., Bathurst, J.C., and Thorne, C.R., Gravel-bed rivers, fluvial processes, engineering and management: New York, Wiley, p. 109-137.

Burbank, W.S., Eckel, E.B., and Varnes, D.J., 1947, The San Juan region, in Vandenvilt, J.W., Mineral resources of Colorado: Denver, Colo., Mineral Research Board, p. $396-446$.

Capesius, J.P., and Stephens, V.C., 2009, Regional regression equations for estimation of natural streamflow statistics in Colorado: U.S. Geological Survey Scientific Investigations Report 2009-5136, 46 p. 
Elliott, J.G., and Capesius, J.P., 2009, Geomorphic changes resulting from floods in reconfigured gravel-bed river channels in Colorado, USA, in James, L.A., Rathburn, S.L., and Whittecar, G.R., eds., Management and restoration of fluvial systems with broad historical changes and human impacts: Boulder, Colo., Geological Society of America Special Paper 451, p. 173-198.

Elliott, J.G., and Parker, R.S., 1999, Reconfigured-channel monitoring and assessment program: U.S. Geological Survey Water-Resources Investigations Report 99-4111, 6 p.

Environmental Systems Research Institute, Inc., 2010, ArcGIS-A complete integrated system: Redlands, Calif., Environmental Systems Research Institute, Inc., accessed Oct. 17, 2011, from http://www.esri.com/software/arcgis/.

Freeman, L.A., Carpenter, M.C., Rosenberry, D.O., Rousseau, J.P., Unger, R., and McLean, J.S., 2004, Use of submersible pressure transducers in water-resources investigations: U.S. Geological Survey Techniques of Water-Resources Investigations, book 8, chap. A, 65 p.

Guzzi, Raffaela, and Parise, Mario, 1992, Surface features and kinematics of the Slumgullion landslide, near Lake City, Colorado: U.S. Geological Survey Open-File Report 92-252, 45 p.

Helsel, D.R., and Hirsch, R.M., 2002, Statistical methods in water resources: U.S. Geological Survey Techniques of Water-Resources Investigation, book 4, chap. A3, 523 p.

Hickman, Terry, and Raleigh, R.F., 1982, Habitat suitability index models - Cutthroat trout: U.S. Fish and Wildlife Service Biology Report, vol. 82, no. 10.5, 38 p.

Hirsch, R.M., 1982, A comparison of four streamflow record extension techniques: Water Resources Research, v. 18, no. 4, p. 1081-1088.

Homer, Collin, Huang, Chengquan, Yang, Limin, Wylie, B.K., and Coan, Michael, 2004, Development of a 2001 National Land Cover database for the United States: Photogrammetric Engineering and Remote Sensing, v. 70, no. 7, p. 829-840.

Julien, P.Y., 2010, Erosion and sedimentation second edition: Cambridge, United Kingdom, The Cambridge University Press, $371 \mathrm{p}$.

Komar, P.D., 1987, Selective gravel entrainment and the empirical evaluation of flow competence: Sedimentology, v. 34, p. 1165-1176.

Lake Fork Valley Conservancy, 2010, Lake Fork River restoration project: Lake City, Colo. ,Lake Fork Valley Conservancy, $4 \mathrm{p}$.

Lemmon, P.E., 1956, A spherical denisometer for estimating forest overstory density: Forest Service Science, v. 2, no. 4, 314-320 p.
Leopold, L.B., and Wolman, M.G., 1957, River channel patterns - Braided, meandering and straight: U.S. Geological Survey Professional Paper 282-B, p. 39-84.

Lindsey, B.D., Breen, K.J., Bilger, M.D., and Brightbill, R.A., 1998, Water quality in the lower Susquehanna River Basin, Pennsylvania and Maryland, 1992-95: U.S. Geological Survey Circular 1168, accessed April 10, 2012, at http://pubs. er.usgs.gov/publication/cir1168.

Lisle, T.E., Nelson, J.M., Pitlick, John, Madej, M.A., and Barkett, B.L., 2000, Variability of bed mobility in natural, gravel-bed channels and adjustments to sediment load at local and reach scales: Water Resources Research, v. 26, no. 12 , p. $3743-3755$.

McDonald, R.R., Bennett, J.P., and Nelson, J.M., 2001, The USGS Multi-Dimensional Surface Water Modeling System, in Seventh Federal Interagency Sedimentation Conference, March 25-29, 2001, Reno, Nev., Proceedings: SEDHYD, p. I161-I-167, accessed April 5, 2011, at http:// pubs.usgs.gov/misc/FISC_1947-2006/pdf/1st-7thFISCsCD/7thFISC/7Fisc-V1/7FISC1-1.pdf.

McDonald, R.R., Nelson, J.M., and Bennett, J.P., 2005, Multidimensional surface-water modeling system user's guide: U.S. Geological Survey Techniques and Methods, book 6, chap. B2, 156 p.

McDonald, R.R., Nelson, J.M., Kinzel, P.J., and Conaway, J., 2006, Modeling surface-water flow and sediment mobility with the Multi-Dimensional Surface Water Modeling System (MD_SWMS): U.S. Geological Survey Fact Sheet 2005-3078, 6 p.

Milhous, R.T., 1982, Effect of sediment transport and flow regulation on the ecology of gravel-bed rivers, in Hey, R.D., Bathhurst, J.C., and Thorne, C.R., eds., Gravel-bed rivers: Chichester, England, Wiley, p. 819-842.

Millar, R.G., and Quick, M.C., 1994, Flow resistance of highgradient gravel channels, in Cotroneo, G.V., and Rumer. R.R. (eds.), Hydraulic engineering '94: American Society of Civil Engineers, Buffalo, N.Y., p. 717-721.

Mueller, D.S., and Wagner, C.R., 2009, Measuring discharge with acoustic Doppler current profilers from a moving boat: U.S. Geological Survey Techniques and Methods 3A-22, $72 \mathrm{p}$.

Nelson, J.M., Bennett, J.P., and Wiele, S.M., 2003, Flow and sediment-transport modeling, in Kondolf, G.M., and Piegay, H., eds., Tools in fluvial geomorphology: Chichester, England, Wiley, p. 539-576.

Nelson, J.M., and McDonald, R.R., 1997, Mechanics and modeling of flow and bed evolution in lateral separation eddies: Bureau of Reclamation, Glen Canyon Environmental Studies Report, $69 \mathrm{p}$. 
Parker, Gary, Klingman, P.C., and McLean, D.G., 1982, Bedload and size distribution in paved gravel-bed streams: American Society of Civil Engineers, Journal of the Hydraulics Division 108(HY4), p. 544-571.

Pielke, R.A., Sr., Doesken, N., and Bliss, O., 2003, Climate of Colorado-Climatology report 60: Fort Collins, Colo., Colorado State University, Department of Atmospheric Science.

Powell, D.M., and Ashworth, P.J., 1995, Spatial pattern of flow competence in bed load transport in a divided gravel bed river: Water Resources Research, v. 31, no. 3, p. 741-752.

Raleigh, R.F., Zuckerman, L.D., and Nelson, P.C., 1986, Habitat suitability index models and in stream flow suitability curves-Brown trout, revised: U.S. Fish Wildlife Service Biology Report, vol. 82, no. 10.124, 65 p.

Rantz, S.E., and others, 1982, Measurement and computation of streamflow-Volume 1, Measurement of stage and discharge: U.S. Geological Survey Water-Supply Paper 2175, v. 1, p. $1-284$.

Richards, Keith, 1982, Rivers-Form and process in alluvial channels: London, Methuen, 358 p.

Thompson, D.M., Nelson, J.M., and Wohl, E.E., 1998, Interactions between pool geometry and hydraulics: Water Resources Research, v. 34, no. 12, p. 3673-3681.

Trimble Navigation Limited, 2009, Trimble ${ }^{\circledR}$ R8 GNSS receiver user guide, version 4.11, revision A: Dayton, Ohio, Trimble Navigation Limited, 50 p., accessed Nov. 4, 2011, at http://www.al-top.com/sites/default/files/0Trimble_ R8-R6-R4-5800M3_ENG.pdf.

Turnipseed, D.P., and Sauer, V.B., 2010, Discharge measurements at gaging stations: U.S. Geological Survey Techniques and Methods, book 3, chap. A8, 87 p.

Tweto, Ogden, comp., 1979, Geologic map of Colorado: U.S. Geological Survey Map, scale 1:500,000.

Tweto, Ogden, and Sims, P.K., 1963, Precambrian ancestry of the Colorado Mineral Belt: Geological Society of America Bulletin, v. 74, p. 991-1014.

U.S. Census Bureau, 2011, Population finder: U.S. Census Bureau, accessed June 26, 2011, http://www.census.gov/.

U.S. Department of Agriculture, 2009, Part 654-Stream restoration design: U.S. Department of Agriculture, National Engineering Handbook, $714 \mathrm{p}$.

U.S. Geological Survey, 2010a, 09124500 Lake Fork at Gateview, CO: U.S. Geological Survey Water Data Report, accessed August 9, 2011, http://wdr.water.usgs.gov/wy2010/ pdfs/09124500.2010.pdf.

U.S. Geological Survey, 2010b, StreamStats - Colorado: U.S. Geological Survey, accessed August 9, 2011, http://water. usgs.gov/osw/streamstats/colorado.html.
Western Regional Climate Center, 2011, Colorado climate summaries: Western Regional Climate Center, accessed June 26, 2011, http://www.wrcc.dri.edu/climate-summaries/.

Wilcock, P.R., and McArdell, B.W., 1993, Surface-based fractional transport rates-Mobilization thresholds and partial transport of a sand-gravel sediment: Water Resources Research, v. 29, no. 4, p. 1297-1312.

Wolman, M.G., 1954, A method of sampling coarse river-bed material: American Geophysical Union Transactions, v. 35, p. $951-956$.

Publishing support provided by:

Denver Publishing Service Center, Denver, Colorado

For more information concerning this publication, contact: Director, USGS Colorado Water Science Center

Box 25046, Mail Stop 415

Denver, CO 80225

(303) 236-4882

Or visit the Colorado Water Science Center Web site at: http://co.water.usgs.gov/ 


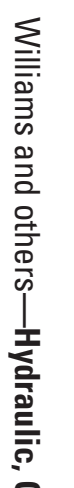

(2)

흘.

言

콩

종 